\title{
OPEN New constraints on the postglacial shallow-water carbonate accumulation in the Great Barrier Reef
}

\author{
Gustavo Hinestrosa ${ }^{1 凶}$, Jody M. Webster ${ }^{1} \&$ Robin J. Beaman ${ }^{2}$
}

More accurate global volumetric estimations of shallow-water reef deposits are needed to better inform climate and carbon cycle models. Using recently acquired datasets and International Ocean Discovery Program (IODP) Expedition 325 cores, we calculated shallow-water $\mathrm{CaCO}_{3}$ volumetrics and mass for the Great Barrier Reef region and extrapolated these results globally. In our estimates, we include deposits that have been neglected in global carbonate budgets: Holocene Halimeda bioherms located on the shelf, and postglacial pre-Holocene (now) drowned coral reefs located on the shelf edge. Our results show that in the Great Barrier Reef alone, these drowned reef deposits represent ca. $135 \mathrm{Gt} \mathrm{CaCO}_{3}$, comparatively representing 16-20\% of the younger Holocene reef deposits. Globally, under plausible assumptions, we estimate the presence of ca. $8100 \mathrm{Gt} \mathrm{CaCO}_{3}$ of Holocene reef deposits, ca. $1500 \mathrm{Gt} \mathrm{CaCO}_{3}$ of drowned reef deposits and ca. $590 \mathrm{Gt} \mathrm{CaCO}_{3}$ of $\mathrm{Halimeda}$ shelf bioherms. Significantly, we found that in our scenarios the periods of pronounced reefal mass accumulation broadly encompass the occurrence of the Younger Dryas and periods of $\mathrm{CO}_{2}$ surge (14.9-14.4 ka, 13.0-11.5 ka) observed in Antarctic ice cores. Our estimations are consistent with reef accretion episodes inferred from previous global carbon cycle models and with the chronology from reef cores from the shelf edge of the Great Barrier Reef.

The role of calcium carbonate deposits in the carbon cycle, and the influence on climate change during the lateQuaternary is poorly constrained. The fifth assessment report of the Intergovernmental Panel on Climate Change ${ }^{1}$ identifies the major contributors for atmospheric $\mathrm{CO}_{2}\left(\right.$ atm- $\left.-\mathrm{CO}_{2}\right)$ concentration changes from the last glacial maximum (LGM) to present. The authors assigned a medium degree of confidence to the current estimates of atm- $\mathrm{CO}_{2}$ contributions from coral reef accretion and carbonate compensation depth changes. This uncertainty derives not just from the use of proxy data and their limited availability, but from the complex relationships between the carbon and other biogeochemical cycles. Such uncertainty is reflected in the range of the contributions to postglacial atm- $\mathrm{CO}_{2}$ attributed to shallow-water reefs in global carbon models $\left(-9\right.$ to $\left.30 \mathrm{ppm}^{2-5}\right)$.

The role that coral reefs may have played in this process has been termed the coral reef hypothesis ${ }^{5-7}$. This hypothesis proposes that the increase of the atm- $\mathrm{CO}_{2}$ is at least partly due to the enhanced shallow-water $\mathrm{CaCO}_{3}$ accretion by corals. This hypothesis relies on the availability of new areas of marine flooded shelf during the last transgression and on the consequent increase in coral reef development. This would have changed the alkalinity balance, at least locally, and ultimately increasing the transfer of $\mathrm{CO}_{2}$ to the atmosphere ${ }^{6,8}$. Because of the reduced marine shelf area during glacial times and the subsequent increase in reef area from glacial to Holocene times, it is assumed that the coral reefs acted as secondary amplifiers-not precursors-of a climatic change that had already initiated ${ }^{9,10}$ with early atm- $\mathrm{CO}_{2}$ rise generally preceding global surface temperature increase $\mathrm{e}^{11}$.

The coral reef hypothesis is supported by the extensive coral reefs of Holocene age worldwide ${ }^{12-16}$. Moreover, a possible lower contribution from terrestrial sources in this same period ${ }^{3,17}$ argues in favour of alternative carbon sources, such as that represented by reef accretion. Simplified box models ${ }^{6,7}$ have suggested that the activity of the coral reefs can explain a significant rise of the atm- $\mathrm{CO}_{2}$ during postglacial times. However, the dissolution ratios, accretion rates and calcite saturation depth informing these models are poorly constrained and they possibly overestimate the total carbon derived from corals.

More complex models have considered the effect of coral reefs in postglacial atm- $\mathrm{CO}_{2}{ }^{2-5,18,19}$. Notably, Ridgwell et al. ${ }^{5}$ inferred two possible minor episodes of global reef growth from 17.0 to $13.8 \mathrm{ka}$ BP and from 12.3

${ }^{1}$ Geocoastal Research Group, School of Geosciences, The University of Sydney, Sydney, Australia. ${ }^{2}$ College of Science and Engineering, James Cook University, Cairns, Australia. ${ }^{\circledR}$ email: gustavo.hinestrosa@sydney.edu.au 


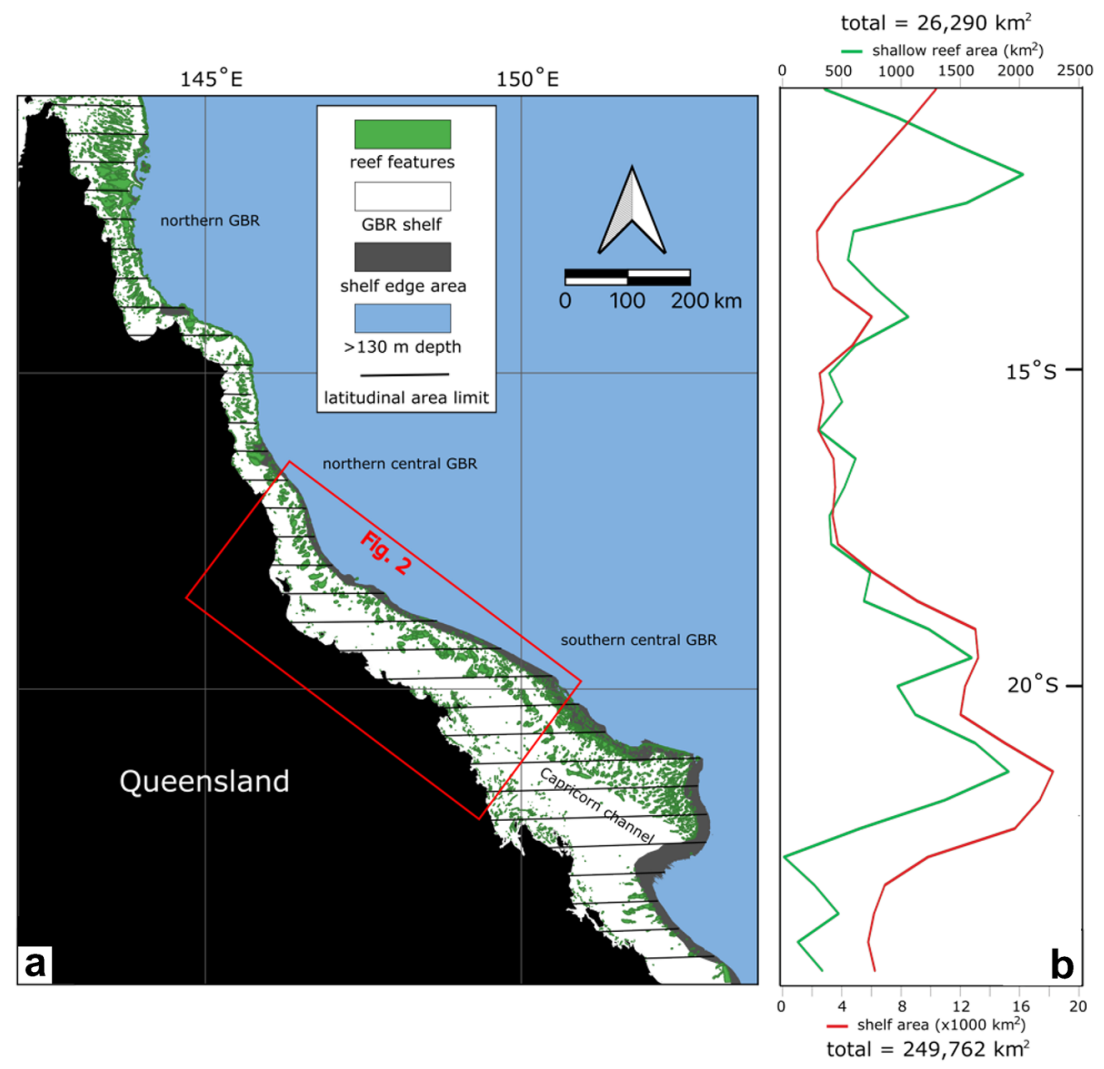

Figure 1. Regional location: (a) Present day coastline and bathymetry of the GBR shelf, from Fraser Island in the south to Cape York in the north. Note the shallow reef presence map as interpreted from satellite imagery and bathymetric data ${ }^{29,50}$ and the latitudinal areas. (b) Shelf area and Holocene reef area as calculated for each latitudinal zone. Note the high correlation of the two curves in the central GBR.

to $11.2 \mathrm{ka}$ BP. With no conclusive evidence available at that time for such global reef growth episodes ${ }^{20}$, they attributed the increase in $\mathrm{CO}_{2}$ to changes in the biogeochemical properties of the Southern Ocean surface.

Interestingly, recent evidence in Tahiti and the Great Barrier Reef (GBR) has revealed glacial and earlypostglacial (30 to $10 \mathrm{ka} \mathrm{BP}$ ) coral reef episodes in line with those inferred intervals (IODP Expeditions 310 \& $325^{21,22}$. Globally, drowned reefs may constitute an important fraction of postglacial carbonate ${ }^{21,23,24}$ and an alternative earlier source of postglacial carbon. Halimeda bioherms are another contributing component, with recent investigations from the GBR suggesting they are volumetrically relevant in postglacial carbonate budgets ${ }^{25-27}$.

Estimations of global and regional reef carbonate area and volume have been attempted using a range of assumptions $s^{13,15,28}$ and applying parameters (e.g. reef area) with large associated uncertainties. New datasets are, however, providing valuable constraints to these parameters within the GBR region. For example, new GIS datasets of reef boundaries ${ }^{29}$ have the potential to improve the estimations of reef area. Additionally, the recent surveys and investigations on the drowned shelf edge reefs of the GBR represent the most complete dataset investigating drowned reefs: IODP Exp. 325 well-dated fossil reef cores $^{30,31}$, seismic lines ${ }^{32,33}$, multibeam bathymetry ${ }^{34}$, and surface sediment and rock dredge samples ${ }^{35,36}$. New detailed bathymetry and interpretations are also providing new constraints on the spatial distribution and volume of Halimeda bioherms in the northern $\mathrm{GBR}^{26,27}$.

In this paper we investigate the impact of drowned coral reefs and Halimeda deposits on regional (GBR shelf, northeastern Australia) and global postglacial shallow-water $\mathrm{CaCO}_{3}$ budgets. Our scientific objectives are to: (1) estimate the volume, mass and timing of postglacial shallow calcium carbonate deposition across the entire GBR using the most recent GIS datasets, data from two IODP Exp. 325 control zones from the shelf-edge reef system and the regional volume of the Halimeda bioherms; (2) extend the resulting volumetric and mass estimates globally based on assumptions ground-truthed in the GBR; and (3) compare our results with past regional and global volumetric and mass estimates.

\section{Regional setting}

The GBR shelf along the northeastern coast of Australia (Fig. 1) accommodates a thick succession of reef deposits over the last $600 \pm 280 \mathrm{ky}^{37,38}$ controlled by major glacial-interglacial sea-level fluctuations. The last glacialinterglacial fluctuation initiated during the $\mathrm{LGM}^{21,30}$ when sea level was approaching minimum levels $(120-130 \mathrm{~m}$ below present) $)^{31,39}$.

As the glaciation ended and sea level rose during the postglacial, extensive fringing- and barrier-reef structures developed along the shelf edge of the GBR until ca. $10 \mathrm{ka} \mathrm{BP}{ }^{21,40}$. These reefs currently lie between 40 and 

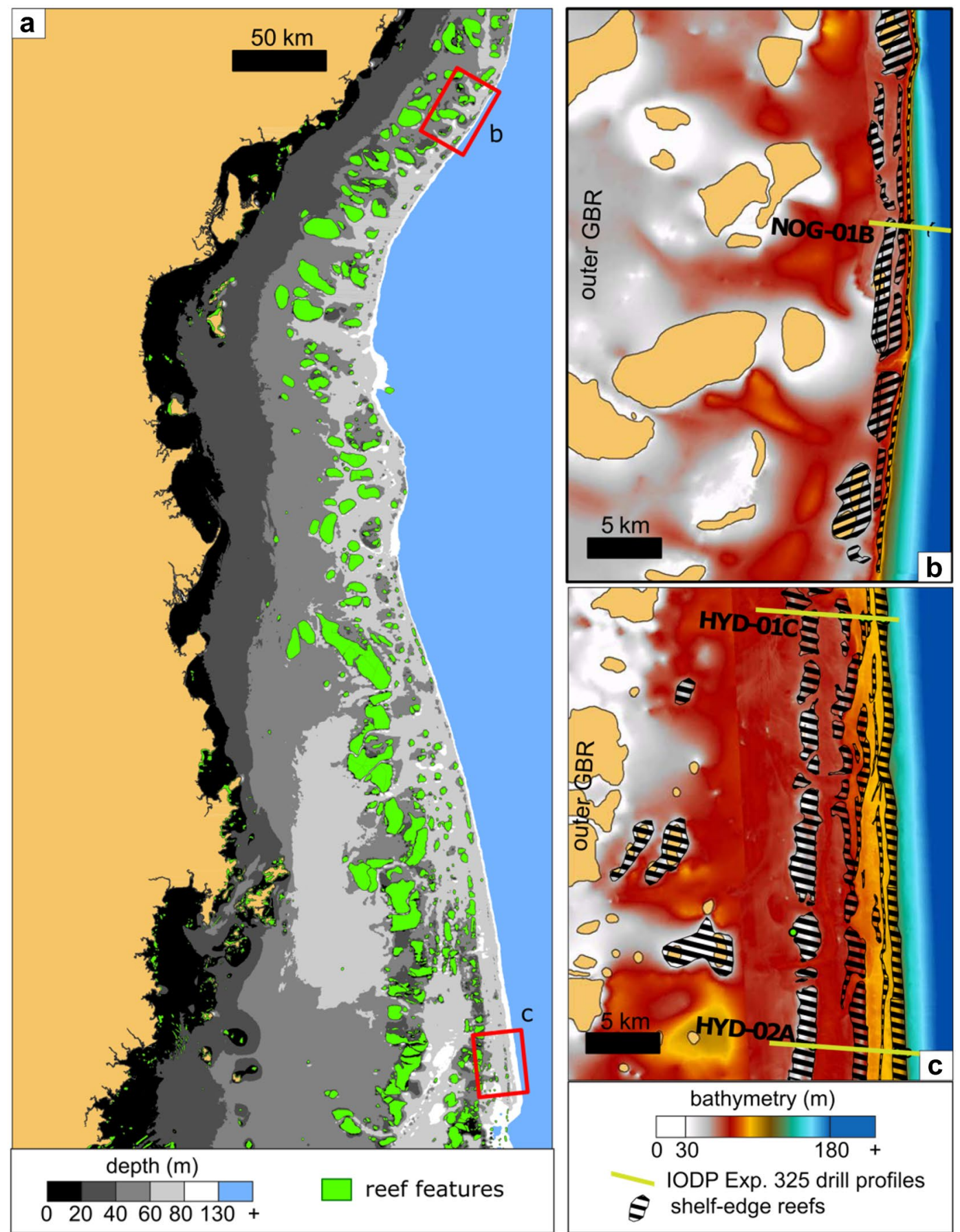

Figure 2. Central GBR and control zones: (a) Bathymetry of the central GBR with shallow reef presence map as interpreted from satellite imagery and bathymetric data ${ }^{29}$, and the locations of the control zones in the vicinity of Noggin Passage and Hydrographers Passage. (b) Noggin Passage in the northern central GBR has a narrower shelf edge reef area. (c) Hydrographer's Passage in the southern central GBR. Note the reef area as estimated for the shelf edge and the location of the seismic and IODP Exp. 325 drilling transects NOG-01B, HYD-01C, HYD$02 \mathrm{~A}^{30,40}$.

$130 \mathrm{~m}$ below present sea level and extend for more than $2000 \mathrm{~km}$ from the northern to the southern central GBR and possibly farther ${ }^{34,41,42}$ (Fig. 2). Beyond the $130 \mathrm{~m}$ depth contour, the shelf edge fore-reef sediments give way to hemipelagic sediments of carbonate and terrigenous origin on the upper continental slope ${ }^{43-45}$. Evidence suggests that the inter-reef areas of the shelf edge are covered by a relatively thin $(0-5 \mathrm{~m})$ layer of carbonate sands and mud, dominated by Halimeda fragments, foraminifera, mollusks and bryozoans ${ }^{35,36,46,47}$.

The shallower structures of the modern GBR were colonized after ca. $9 \mathrm{ka}$ BP following the demise of the shelf-edge reefs. Since then, extensive reef development has occurred along the whole GBR from the vicinity of 
Fraser Island in the south, to Cape York in the north ${ }^{20,48}$. Both Pleistocene and Holocene reef deposits in the GBR display local and regional variations that are the expression of broader physiographic trends and of the physical processes linked to the postglacial marine flooding ${ }^{34,40,49}$.

\section{Results and discussion}

Holocene carbonate deposits. We estimated the areal trends of the Holocene reefs in the GBR. Reef area was estimated from GIS layers containing polygons representing the outline of the Holocene reefs (Figs. 1 and 2). This layer was obtained from a detailed interpretation of recently available satellite images and shallow bathymetry ${ }^{29,50}$, and excluding continental islands and shelf-edge reefs. These features were sliced into latitudinal $50 \mathrm{~km}$ wide slices to assess latitudinal variations. We assumed that the reef area polygons represented the main reef and bioclastic deposits directly related to Holocene reef growth. However, unaccounted fore- and back-reef aprons may constitute a significant portion of the reefal carbonate volume ${ }^{15,51}$.

We estimated the mass of the Holocene $\mathrm{CaCO}_{3}$ deposits by multiplying the area derived from the interpreted GIS layer by the thickness derived from historical reef cores that have drilled through the Holocene (Appendix 1) and petrophysical parameters (Aragonite density, $\rho_{A}=2930 \mathrm{~kg} \mathrm{~m}^{-3}$ and formation porosity, $\Phi_{\mathrm{R}}=35 \%{ }^{30}$ ). The volumetric and mass calculations were also performed at a sub-regional level in $50 \mathrm{~km}$ wide latitudinal slices that allowed reconstruction of latitudinal trends (Fig. 3e, Appendix 2).

Our area estimations show that Holocene reefs occupy approximately $10 \%$ of the total GBR shelf area, following a latitudinal trend that correlates with the total shelf area, especially in the central GBR $\left(R^{2}=0.84\right)$ between $14^{\circ}$ and $21^{\circ} \mathrm{S}$ (Figs. 1,3e). This reflects the direct relationship between substrate availability on the shelf and carbonate accumulation. Interestingly, in the northern GBR (near $12^{\circ} \mathrm{S}$ ) the proportion of Holocene reef area-to-shelf area increases due to the wide (up to $30 \mathrm{~km}$ ) reef structures. The seemingly obvious relationship is, however, a complex one and highly dependent on environmental variables (terrigenous flux, circulation, antecedent substrate, etc.) that can determine the spatial distribution of the carbonate deposits ${ }^{40,49,52-54}$.

Our new GBR Holocene $\mathrm{CaCO}_{3}$ mass estimates (Table 1) fall between the figures by Rees ${ }^{13}$ and Kinsey and Hopley ${ }^{55}$. The Rees ${ }^{13}$ reef area estimate of $44,920 \mathrm{~km}^{2}$, based on Spalding et al. ${ }^{56}$ dataset, is larger than the area presented in this study $\left(26,290 \mathrm{~km}^{2}\right.$, Table 2$)$. Their Holocene $\mathrm{CaCO}_{3}$ estimate is consequently higher $(1709 \mathrm{Gt}$ $\mathrm{CaCO}_{3}$ ) than our best estimate of $751 \mathrm{Gt} \mathrm{CaCO}_{3}$. However, Rees ${ }^{13}$ include reefs in the Australian region that are not part of the GBR system sensu stricto. The Kinsey and Hopley ${ }^{55}$ estimated reef area value is more in agreement with our figure: ca. 20,000 $\mathrm{km}^{2}$. A more recent estimate places the GBR's shallow-water reef area at $16,110 \mathrm{~km}^{250}$, but they do not include sediment wedges associated with these reefs, which are found at greater depths and constitute up to the double of the reef framework volume ${ }^{15,51}$. If we calculate the mass areal accumulation (MAA) using Rees ${ }^{13}$ estimates (Table 1) the resulting MAA is much higher $\left(38,045 \mathrm{~kg} \mathrm{~m}^{-2}\right)$ than even the highest MAA in Hydrographers Passage $\left(27,648 \mathrm{~kg} \mathrm{~m}^{-2}\right.$, Table 2), which seems unlikely. Even applying matching reef areas to Rees ${ }^{13}$ and Kinsey and Hopley ${ }^{55}$ results, these past estimates probably overestimate the Holocene carbonate deposits in the GBR.

Shelf edge reef $\mathrm{CaCO}_{3}$ accumulation. The volume and mass of the shelf edge deposits at a regional scale were ground-truthed in two control zones along the shelf edge of the GBR: Hydrographers Passage and Noggin Passage (Fig. 2). Here, extensive IODP drilling, bathymetric and seismic surveys ${ }^{30,34,40,47}$ provided valuable data for the calibration of the parameters required for the regional reconstruction of volumetrics and mass: reef area ratio, formation volume from seismic imaging, mass areal accumulation (MAA), vertical accretion rate, the maximum cumulative thickness and petrophysical parameters. A regional bathymetric dataset ${ }^{57}$ provided the basis for the reconstruction for the postglacial marine flooded area in the GBR (analogous to Hinestrosa et al. ${ }^{49}$ ).

Two methods were applied to obtain the volumetrics and mass of the shelf-edge deposits: (1) the mass areal accumulation method and (2) the postglacial thickness method. The former is a bulk calculation of volume based on flooded area and the accumulation represented by the $M A A$, scaled back by the proportion of bathymetric surface covered by reefs (reef area ratio) without considering any temporal evolution. The latter, the postglacialthickness method, attempts to reconstruct the temporal evolution of the reef accretion by considering the change in flooded area since the LGM. It is layer-based, with each layer corresponding to a $5 \mathrm{~m}$ sea-level step in which data-derived thickness constraints (Fig. 4a, Appendix 3) are applied in such a way that vertical reef accumulation does not exceed observed thicknesses (Fig. 4b). It relies on the assumption that the reef area ratio, vertical accretion rate and maximum cumulative thickness values observed in the control zones can be extended to other locations along the GBR shelf edge. A composite sea-level curve based on Lambeck et al. ${ }^{39}$ and Yokoyama et al. ${ }^{31}$ (Fig. 5, Appendix 6) enabled the translation between past sea levels and geological ages to reconstruct the temporal evolution of the deposits.

The estimates obtained applying the mass areal accumulation method are lower than those estimated by applying the postglacial thickness method but are within the same order of magnitude. Not surprisingly, the application of both methods results in similar latitudinal trends (Fig. 3e) because in both the flooded area is a direct factor in the calculations.

Control zones. In the control zones, Noggin Passage and Hydrographers Passage (Fig. 2), ca. 20\% of the shelf edge is covered in reef structures (i.e., reef area ratio $=$ ca. $20 \%$ ). This proportion is almost twice the reef area ratio estimated at a regional scale for the shallower, Holocene reefs when considering the whole of the GBR shelf.

In both control zones (Table 2) we found that reef areas have MAA values above $10,000 \mathrm{~kg} \mathrm{~m}^{-2}$, whilst interreef areas display MAA values that are an order of magnitude lower $\left(7767-8406 \mathrm{~kg} \mathrm{~m}^{-2}\right)$. The southern control zone (Hydrographers Passage) has a higher average MAA (e.g., 20,393-35,003 $\mathrm{kg} \mathrm{m}^{-2}$ in the outer barrier) than the northern site (Noggin Passage) in all the geomorphic areas assessed (e.g., 14,726-19,586 $\mathrm{kg} \mathrm{m}^{-2}$ in the outer 


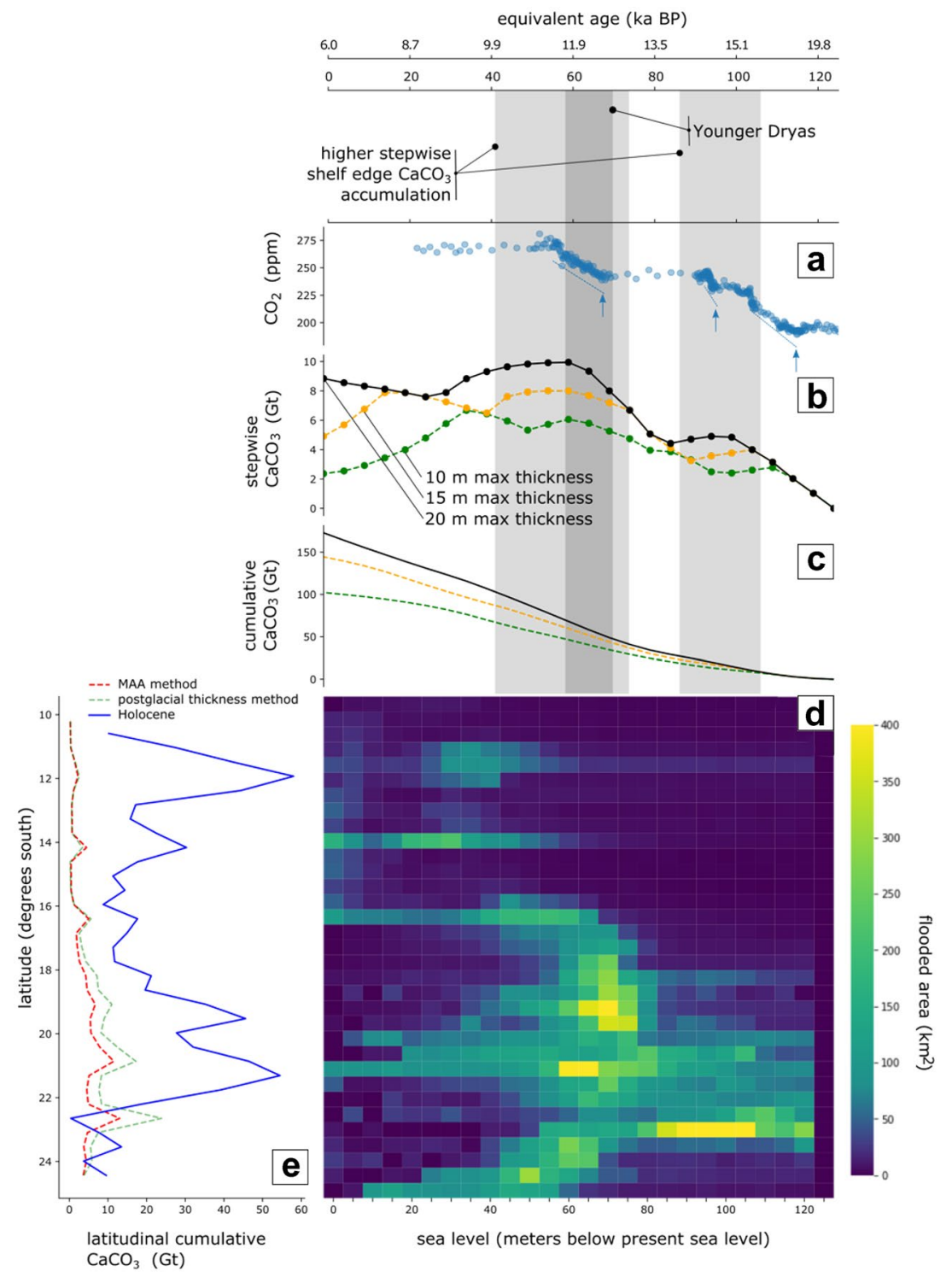

Figure 3. Summary of shelf edge reef deposits in the GBR: (a) atm- $\mathrm{CO}_{2}{ }^{67}$ data from Antarctic ice cores, intervals of increased rate are highlighted in blue; (b) stepwise shelf edge reef deposits; (c) cumulative shelf edge $\mathrm{CaCO}_{3}$ increase for different maximum accretion thicknesses, (d) shelf edge $\mathrm{CaCO}_{3}$ mass deposits for every latitudinal zone and for every past sea level $5 \mathrm{~m}$ increase; (e) comparison of the latitudinal distribution of $\mathrm{CaCO}_{3}$ mass deposits (best-estimate case) for the Holocene reefs and the shelf edge reefs according to the two applied methods. Notice the increase of the values between $18^{\circ}$ and $22^{\circ} \mathrm{S}$ where the shelf is wider.

barrier). This is consistent with a thinner reef veneer $(<10 \mathrm{~m})$ in the terrace and outer geomorphic areas and less distinguishable barrier structures found at Noggin Passage ${ }^{40}$.

Shelf edge trends. Volumetrically, the carbonate deposits of the shelf edge wane in the northern GBR when compared to the central and southern GBR (Fig. 3d, e). In the northern GBR, the Holocene and the shelf edge pre-Holocene reef trends are also contrasting: the Holocene reef deposits increase dramatically near $12^{\circ} \mathrm{S}$, whereas the shelf edge deposits at those latitudes diminish, possibly due to limited substrate availability ${ }^{40}$. On the contrary, in the southern-central GBR (e.g. Hydrographers Passage control zone) wider and a more gentle gradient provides more substrate availability ${ }^{34}$.

It is useful to establish some comparisons to appreciate the magnitude of the shelf edge deposits. At the shelf edge, our estimates suggest that the area covered by reef formations is between 3000 and $11,000 \mathrm{~km}^{2}($ Table 1$)$, which would represent $8 \%$ (minimum case) to $30 \%$ (maximum case) of the total area occupied by all the banks in Harris et al. $^{50}$, and between $12 \%$ (minimum case) and $48 \%$ (maximum case) of the area occupied by banks with no Holocene cover in that same study. Kleypas ${ }^{58}$ inferred that the global area available for reef growth during the LGM lowstand was approximately $20 \%$ of that available today. In the GBR, that figure is at least within the 


\begin{tabular}{|c|c|c|c|c|c|c|c|c|c|c|c|}
\hline Study & $\begin{array}{l}\text { Kinsey and } \\
\text { Hopley }^{55}\end{array}$ & $\operatorname{Rees}^{13}$ & \multicolumn{9}{|c|}{ This study } \\
\hline Feature & Holocene reefs & $\begin{array}{l}\text { Holocene } \\
\text { reefs }\end{array}$ & \multicolumn{3}{|c|}{ Holocene reefs } & \multicolumn{6}{|c|}{ SERs (postglacial thickness method) } \\
\hline $\begin{array}{l}\text { Dataset/ } \\
\text { observations }\end{array}$ & $\begin{array}{l}\mathrm{CaCO}_{3} \text { mass } \\
\text { based on } \\
\text { accumulation } \\
\text { rate }(0.049 \mathrm{Gt} \\
\left.\mathrm{CaCO}_{3} \mathrm{y}^{-1}\right) \\
\end{array}$ & Rees $^{13}$ & \multicolumn{3}{|c|}{ Interpretation of reef features, Harris et al. ${ }^{50}$} & \multicolumn{6}{|c|}{ Beaman $^{57}$, Webster et al. ${ }^{30}$, Hinestrosa et al..$^{40,47}$ and Webster et al..$^{21}$} \\
\hline Scenario & 8 to 0 ka BP & 10 to $0 \mathrm{ka} \mathrm{BP}$ & Min & Best est & Max & Min & Best Est & $\operatorname{Max}$ & \multicolumn{3}{|c|}{$100 \%$ reef-area ratio } \\
\hline Reef area $\left(\mathrm{km}^{2}\right)$ & 20,055 & 44,920 & \multicolumn{3}{|l|}{26,290} & 2870 & 5741 & 11,482 & \multicolumn{3}{|l|}{28,704} \\
\hline $\begin{array}{l}\text { Average reef } \\
\text { thickness }(\mathrm{m})\end{array}$ & 13 & 26 & 10 & 15 & 20 & 10 & 15 & 20 & \multicolumn{3}{|l|}{15} \\
\hline $\begin{array}{l}\text { Total volume } \\
\text { above } 130 \mathrm{mbsl} \\
\left(\mathrm{km}^{3}\right)\end{array}$ & 270 & 1179 & 273 & 394 & 526 & 27 & 78 & 192 & \multicolumn{3}{|l|}{391} \\
\hline Porosity (\%) & 50 & 50 & 35 & 35 & 35 & 35 & 35 & 35 & \multicolumn{3}{|l|}{35} \\
\hline $\begin{array}{l}\text { Net } \mathrm{CaCO}_{3} \\
\text { volume }\left(\mathrm{km}^{3}\right)\end{array}$ & 135 & 589 & 177 & 256 & 342 & 18 & 51 & 125 & \multicolumn{3}{|l|}{254} \\
\hline Density $\left(\mathrm{kg} \mathrm{m}^{-3}\right)$ & 2900 & 2900 & 2930 & 2930 & 2930 & 2930 & 2930 & 2930 & \multicolumn{3}{|l|}{2930} \\
\hline $\begin{array}{l}\text { Net } \mathrm{CaCO}_{3} \text { mass } \\
\left(\mathrm{Gt} \mathrm{CaCO}_{3}\right)\end{array}$ & 392 & 1709 & 520 & 751 & 1001 & 52 & 149 & 366 & \multicolumn{3}{|l|}{745} \\
\hline $\begin{array}{l}\text { Mass areal } \\
\text { accumulation } \\
\left(\mathrm{kg} \mathrm{m}^{-2}\right)\end{array}$ & 19,546 & 38,045 & 19,776 & 28,568 & 38,090 & 18,047 & 25,943 & 31,914 & \multicolumn{3}{|l|}{25,943} \\
\hline Reef-cover & $9 \%$ & - & \multicolumn{3}{|l|}{$10.5 \%$} & $10 \%$ & $20 \%$ & $40 \%$ & \multicolumn{3}{|l|}{$100 \%$} \\
\hline Study & \multicolumn{11}{|l|}{ This study } \\
\hline Feature & \multicolumn{4}{|c|}{ SERs (MAA method) } & $\begin{array}{l}\text { Halimeda } \\
\text { mounds }\end{array}$ & \multicolumn{3}{|c|}{ Total postglacial (reef) } & \multicolumn{3}{|c|}{ Total postglacial } \\
\hline $\begin{array}{l}\text { Dataset/ } \\
\text { observations }\end{array}$ & \multicolumn{4}{|c|}{ Beaman $^{57}$, Webster et al. ${ }^{30}$ and Hinestrosa et al. ${ }^{40,47}$} & McNeil et al. ${ }^{26}$ & \multicolumn{3}{|c|}{$\begin{array}{l}\text { Holocene values + average of SERs } \\
\text { values }\end{array}$} & \multicolumn{3}{|c|}{$\begin{array}{l}\text { Holocene values + average of SERs } \\
\text { values + Halimeda preliminary } \\
\text { estimate }\end{array}$} \\
\hline Scenario & Min & Best est & Max & $\begin{array}{l}100 \% \text { reef-area } \\
\text { ratio }\end{array}$ & $\begin{array}{l}\text { Only N and } \\
\text { central GBR }\end{array}$ & Min & Best est & Max & Min & Best est & $\operatorname{Max}$ \\
\hline Reef area $\left(\mathrm{km}^{2}\right)$ & 2870 & 5741 & 11,482 & \begin{tabular}{|l|}
28,704 \\
\end{tabular} & 6111 & 29,161 & 32,031 & 37,772 & 35,272 & 38,142 & 43,883 \\
\hline $\begin{array}{l}\text { Average reef } \\
\text { thickness }(\mathrm{m})\end{array}$ & 8 & 11 & 15 & 11 & 8.4 & $14-25$ & $14-25$ & $14-25$ & $5-20$ & $5-25$ & $5-25$ \\
\hline $\begin{array}{l}\text { Total volume } \\
\text { above } 130 \mathrm{mbsl} \\
\left(\mathrm{km}^{3}\right)\end{array}$ & 22 & 61 & 167 & 305 & 51.5 & 298 & 464 & 705 & 349 & 515 & 757 \\
\hline Porosity (\%) & 35 & 35 & 35 & 35 & 58 & 35 & 35 & 35 & $35-50$ & $35-50$ & $35-50$ \\
\hline $\begin{array}{l}\text { Net } \mathrm{CaCO}_{3} \\
\text { volume }\left(\mathrm{km}^{3}\right)\end{array}$ & 14 & 40 & 108 & 198 & 20 & 193 & 302 & 458 & 213 & 321 & 478 \\
\hline Density $\left(\mathrm{kg} \mathrm{m}^{-3}\right)$ & 2930 & 2930 & 2930 & 2930 & 2930 & 2930 & 2930 & 2930 & 2930 & 2930 & 2930 \\
\hline $\begin{array}{l}\text { Net } \mathrm{CaCO}_{3} \text { mass } \\
\left(\mathrm{Gt} \mathrm{CaCO}_{3}\right)\end{array}$ & 42 & 116 & 317 & 581 & 55 & 567 & 884 & 1343 & 622 & 939 & 1398 \\
\hline $\begin{array}{l}\text { Mass areal } \\
\text { accumulation } \\
\left(\mathrm{kg} \mathrm{m}^{-2}\right)\end{array}$ & 14,509 & 20,245 & 27,648 & 20,245 & 9000 & 19,432 & 27,586 & 35,564 & 17,625 & 24,609 & 31,865 \\
\hline Reef-cover & $10 \%$ & $20 \%$ & $40 \%$ & $100 \%$ & - & $10 \%^{*}$ & $20 \%^{*}$ & $40 \%^{*}$ & $10 \%^{*}$ & $20 \%^{*}$ & $40 \%^{*}$ \\
\hline
\end{tabular}

Table 1. GBR estimates of $\mathrm{CaCO}_{3}$ volume, mass and MAA for the Holocene, shelf edge reefs and Halimeda bioherms of the GBR. Rees ${ }^{13}$ and Kinsey and Hopley ${ }^{55}$ estimates are shown for comparison. Bold highlight the parameters applied for calculation. ${ }^{\star}$ Values used for SERs only.

same order of magnitude of our estimations: a maximum shelf edge flooded area of ca. $29,523 \mathrm{~km}^{2}$ (best estimate, Table 1) representing $12 \%$ of the whole GBR shelf (ca. $\left.249,762 \mathrm{~km}^{2}\right)$.

Other carbonate deposits in the GBR. Halimeda bioherms are a significant component of the region's postglacial carbonate budget. A comparison of the most up-to-date morphometric data ${ }^{27}$ shows that the postglacial Halimeda deposits are equivalent in mass to 5.5-10.5\% of the Holocene reef mass on the GBR shelf (Table 1). Halimeda can form mounds in inter-reef areas of the GBR up to a thickness of $20 \mathrm{~m}^{25-27,59,60}$. Recent reviews of published and new high-resolution bathymetry have revealed that at least $6000 \mathrm{~km}^{2}$ of the northern and central GBR are covered by Halimeda bioherms ${ }^{26,27}$. This is a considerable increase from the ca. $2000 \mathrm{~km}^{2}$ from previous estimations ${ }^{59}$.

Halimeda-like morphologies have also been detected on the shelf edge in seismic profiles ${ }^{47}$ and Halimeda floatstones recovered in dredges from the shelf edge dated to 11.8-7.2 ka (D24B, D22, D11B in Abbey et al. ${ }^{36}$ ). 
Despite these new constraints, questions remain about the extent of pre-Holocene Halimeda deposits, particularly at the shelf edge.

Global and regional estimates. We extrapolated the estimates and trends of $\mathrm{CaCO}_{3}$ deposits for the GBR to the entire globe using the reef area estimate of Spalding et al. ${ }^{56}$. Using this area, we applied the parameters ground-truthed in the GBR dataset. The global reef area $\left(\mathrm{RA}_{\mathrm{GLOBAL}}\right)$ was multiplied by average thickness and petrophysical parameters $\left(\rho_{A}, \Phi_{R}\right)$ to obtain global postglacial $\mathrm{CaCO}_{3}$ deposits. We accounted for the drowned postglacial reefs by applying two factors to the global Holocene estimates: a factor based in the ratio of shelf edge-to-Holocene reef area (area adjustment factor, $\mathrm{AF}_{\mathrm{A}}$ ) and a factor based in the mass ratio (mass adjustment factor, $\mathrm{AF}_{\mathrm{M}}$ ) (Table 3). These factors and the global extrapolation as such, have large associated uncertainties given the gaps in knowledge of total global extent, accretion trends and morphology of the less accessible postglacial drowned reefs. We also calculated the global volumetrics and mass globally using the reef areas from past studies (Tables 4, 5; Appendix 4).

We found that the reef area ratio at the shelf edge (ca. 20\%) is twice the reef area ratio estimated for the whole GBR shelf (ca. 10\% for Holocene reefs, Table 1). The structures with Holocene reefs occupy more absolute area but are sparse and separated by large extensions of flat sediment-covered submarine topography. At a global scale, previous studies suggest lower reef area ratio values: reef area $\left(584\right.$ to $\left.746 \times 10^{3} \mathrm{~km}^{2}\right)$ and shelf area in low latitudes $\left(11,686 \times 10^{3} \mathrm{~km}^{2}\right)$ as reported in Kleypas ${ }^{58}$, suggesting a global reef area ratio of 5 to $6 \%$. This percentage would be even lower if we apply the global reef areas of $300 \times 10^{3} \mathrm{~km}^{261}, 255 \times 10^{3} \mathrm{~km}^{216}$ or $284 \times 10^{3} \mathrm{~km}^{256}$. The lower value of the global reef area ratio (5-6\%) compared to the GBR values of this study (ca. 10\%) could be partly explained by uncertainties in the topographic/bathymetric datasets used by Kleypas ${ }^{58}$ (e.g., ETOPO $5^{62}$ ), and by difficulties in predicting reef habitat using the ReefHab model ${ }^{58}$, or by the inclusion of shelf areas that are not potential reef habitats. It is also possible that the GBR had more favourable regional conditions for reef development compared to other global locations.

The global reef area estimate of $284,000 \mathrm{~km}^{2}$ by Spalding et al. ${ }^{56}$ is lower than estimates from other authors (Table 5), but it is based on a more comprehensive dataset compared to other studies. However, this dataset originates from a collection of data from different origins and scales which brings uncertainty, especially at a local scale. Their estimates refer mainly to the area occupied by modern coral reefs and would only represent a proxy for Holocene deposits rather for than the entire postglacial reef system, which should include early-and mid-postglacial drowned reefs.

Applying the global reef area above and the parameters ground-truthed on the GBR shelf, we obtain a global Holocene reef deposits estimate of ca. $8100 \mathrm{Gt} \mathrm{CaCO}_{3}$ in the best-case scenario (Table 3). This is very similar to past estimates reported in Rees et al. ${ }^{63}$ (Table 6). However, we must also consider other calcium carbonate deposits: inter-reef carbonates, Halimeda bioherms and drowned reefs. Applying a similar Halimeda-to-reef ratio to the one estimated in the GBR (Table 1) an extra $592 \mathrm{Gt} \mathrm{CaCO}_{3}$ would be added to the global carbonate budget of the last $8 \mathrm{ky}$ (Table 3). The choice of the global reef area as a parameter is critical: a simple comparison of the same calculations but using areas from other studies (Table 5) reveals a large variation in total postgla-

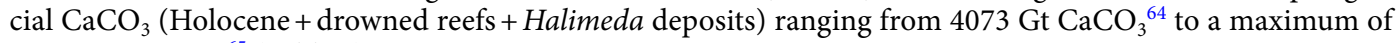
$54,550 \mathrm{Gt} \mathrm{CaCO}_{3}{ }^{65}$ (Table 4).

Incorporating the drowned reefs in global $\mathrm{CaCO}_{3}$ budgets. The role of coral reefs in postglacial oceanic alkalinity changes and atmospheric $\mathrm{CO}_{2}$ input is poorly constrained and partly relies on $\mathrm{CaCO}_{3}$ deposits estimates that are uncertain. The estimates of area covered by shallow-water carbonates, from which some global estimates are derived, are mainly associated with Holocene reefs ${ }^{13,16,61}$ (Table 5) and ignore the more elusive (now) drowned, deeper deposits. The submerged reefs discovered in different parts of the world ${ }^{21,23,24}$ should be incorporated into updated postglacial $\mathrm{CaCO}_{3}$ deposits estimates.

In the GBR, there is strong evidence of almost continuous shallow reef accretion from ca. $30 \mathrm{until}$ ca. $9.5 \mathrm{ka}$ $\mathrm{BP}$ along the shelf edge, albeit characterised by five brief demise events ${ }^{21}$. We estimate that the total net $\mathrm{CaCO}_{3}$ deposits of the submerged shelf-edge reefs are equivalent to ca. 16 to $20 \%$ of the Holocene reef deposits mass in our best-estimate scenario, and up to ca. $40 \%$ if we consider higher values of reef area ratio, postglacial reef thickness or mass areal deposits (Table 1).

If we extend the shelf edge-to-Holocene reef ratios estimated in the GBR to global scales (mass adjustment factor $\mathrm{AF}_{\mathrm{M}}$ and areal adjustment factor $\mathrm{AF}_{\mathrm{A}}$ ), we obtain a global value of $1460-1785 \mathrm{Gt} \mathrm{CaCO}_{3}$ accumulated in the drowned reefs from 19 to $10 \mathrm{ka}$ BP. These results are modest compared to the combined Holocene reef deposits (ca. $8100 \mathrm{Gt}_{\mathrm{CaCO}}$ ). However, given the direct evidence on large-scale pre-Holocene shelf edge reef systems in the GBR (only surveyed at scale in the last decade ${ }^{30}$ ) and past evidence of other large-scale drowned reefs in global locations ${ }^{23,24}$, the question of the impact of drowned reefs on the LGM-to-postglacial global $\mathrm{CaCO}_{3}$ budgets remains relevant.

The impact of the global reef area applied can be assessed by looking at average $\mathrm{CaCO}_{3}$ fluxes for the whole postglacial period (Table 3), which can vary from a minimum of $0.2 \mathrm{Gt} \mathrm{CaCO}_{3} \mathrm{y}^{-1}$ (using area in De Vooys ${ }^{64}$ ) to a maximum of $3.2 \mathrm{Gt} \mathrm{CaCO}_{3} \mathrm{y}^{-1}$ (using area in Copper ${ }^{65}$ ). However, if we split the averages between Holocene and pre-Holocene, we find the differences are of one order of magnitude (1.0 vs $0.2 \mathrm{Gt} \mathrm{CaCO}_{3} \mathrm{y}^{-1}$; Table 3$)$. This can be compared to some recent estimates of reef productivity of $1.9 \mathrm{Gt} \mathrm{CaCO}_{3} \mathrm{y}^{-1}$ for the Holocene and 2.5-4.5 $\mathrm{Gt}_{\mathrm{CaCO}} \mathrm{y}^{-1}$ for the late deglacial ${ }^{19}$, which were hard to reconcile with common carbon cycle models ${ }^{18}$. Our results are more in line with Vecsei and Berger ${ }^{66}$ who considered postglacial drowned reefs and reported values of 0.29-0.51 Gt $\mathrm{CaCO}_{3} \mathrm{y}^{-1}$ for the Holocene and $0.15 \mathrm{Gt} \mathrm{CaCO}_{3} \mathrm{y}^{-1}$ for the mid-late postglacial. 


\begin{tabular}{|c|c|c|c|c|c|c|c|c|c|c|}
\hline \multicolumn{2}{|l|}{ Study area } & \multicolumn{9}{|c|}{ Hydrographers Passage } \\
\hline Stratigraphic unit & & \multicolumn{9}{|c|}{ Unit 1 (postglacial) } \\
\hline Geomorphic zone & & \multicolumn{3}{|c|}{ Entire study area } & \multicolumn{3}{|c|}{ Inner barrier } & \multicolumn{3}{|c|}{ Outer barrier } \\
\hline \multicolumn{2}{|l|}{ Velocity scenario } & Min & Best est & Max & Min & Best est & Max & Min & Best est & Max \\
\hline Area $\left(\mathrm{km}^{2}\right)$ & Polygons digitized on geomorphic maps & 422 & 422 & 422 & 42 & 42 & 42 & 29 & 29 & 29 \\
\hline Total volume $\left(\mathrm{km}^{3}\right)$ & Calculations above $130 \mathrm{mbsl}$ & 2.71 & 3.18 & 3.64 & 0.41 & 0.57 & 0.74 & 0.31 & 0.42 & 0.53 \\
\hline Net carbonate volume $\left(\mathrm{km}^{3}\right)$ & Porosity $=35 \%$ & 1.76 & 2.07 & 2.36 & 0.27 & 0.37 & 0.48 & 0.20 & 0.27 & 0.35 \\
\hline Net carbonate mass $\left(\mathrm{Gt} \mathrm{CaCO}_{3}\right)$ & Density $=2930 \mathrm{~kg} \mathrm{~m}^{-3}$ & 5.16 & 6.06 & 6.93 & 0.78 & 1.09 & 1.40 & 0.59 & 0.80 & 1.02 \\
\hline Mass areal accumulation $\left(\mathrm{kg} \mathrm{m}^{-2}\right)$ & Area as indicated & 12,235 & 14,370 & 16,414 & 18,682 & 26,028 & 33,419 & 20,393 & 27,648 & 35,003 \\
\hline \multicolumn{2}{|l|}{ Reef area cover } & \multicolumn{9}{|l|}{$18.8 \%$} \\
\hline \multicolumn{2}{|l|}{ Study area } & \multicolumn{9}{|c|}{ Hydrographers Passage } \\
\hline \multicolumn{2}{|l|}{ Stratigraphic unit } & \multicolumn{9}{|c|}{ Unit 1 (postglacial) } \\
\hline \multicolumn{2}{|l|}{ Geomorphic zone } & \multicolumn{3}{|c|}{ Inner + outer platform } & \multicolumn{3}{|c|}{ Terrace + shelf-break } & \multicolumn{3}{|c|}{ All barrier (inner + outer) } \\
\hline \multicolumn{2}{|l|}{ Velocity scenario } & Min & Best est & Max & Min & Best est & Max & Min & Best est & Max \\
\hline Area $\left(\mathrm{km}^{2}\right)$ & Polygons digitized on geomorphic maps & 240 & 240 & 240 & 111 & 111 & 111 & 71 & 71 & 71 \\
\hline Total volume $\left(\mathrm{km}^{3}\right)$ & calculations above $130 \mathrm{mbsl}$ & 0.98 & 1.02 & 1.06 & 1.01 & 1.17 & 1.31 & 0.72 & 1.00 & 1.27 \\
\hline Net carbonate volume $\left(\mathrm{km}^{3}\right)$ & Porosity $=35 \%$ & 0.64 & 0.66 & 0.69 & 0.66 & 0.76 & 0.85 & 0.47 & 0.65 & 0.83 \\
\hline Net carbonate mass $\left(\mathrm{Gt} \mathrm{CaCO}_{3}\right)$ & Density $=2930 \mathrm{~kg} \mathrm{~m}^{-} 3$ & 1.86 & 1.94 & 2.02 & 1.92 & 2.23 & 2.49 & 1.38 & 1.89 & 2.42 \\
\hline Mass areal accumulation $\left(\mathrm{kg} \mathrm{m}^{-2}\right)$ & Area as indicated & 7767 & 8092 & 8406 & 17,325 & 20,062 & 22,438 & 19,381 & 26,690 & 34,066 \\
\hline \multicolumn{2}{|l|}{ Reef area cover } & \multicolumn{6}{|l|}{$18.8 \%$} & & & \\
\hline \multicolumn{2}{|l|}{ Study area } & \multicolumn{9}{|c|}{ Noggin Passage } \\
\hline \multicolumn{2}{|l|}{ Stratigraphic unit } & Unit 1 & postglacia & & & & & & & \\
\hline Geomorphic zone & & Entire s & tudy area & & Inner b & Irrier & & Outer b & arrier & \\
\hline Velocity scenario & & Min & Best est & Max & Min & Best est & Max & Min & Best est & Max \\
\hline Area $\left(\mathrm{km}^{2}\right)$ & Polygons digitized on geomorphic maps & 85 & 85 & 85 & 10 & 10 & 10 & 18 & 18 & 18 \\
\hline Total volume $\left(\mathrm{km}^{3}\right)$ & Calculations above $130 \mathrm{mbsl}$ & 0.49 & 0.54 & 0.58 & 0.07 & 0.08 & 0.10 & 0.14 & 0.16 & 0.18 \\
\hline Net carbonate volume $\left(\mathrm{km}^{3}\right)$ & Porosity $=35 \%$ & 0.32 & 0.35 & 0.38 & 0.05 & 0.06 & 0.06 & 0.09 & 0.10 & 0.12 \\
\hline Net carbonate mass $\left(\mathrm{Gt} \mathrm{CaCO}_{3}\right)$ & Density $=2930 \mathrm{~kg} \mathrm{~m}^{-3}$ & 0.93 & 1.02 & 1.11 & 0.13 & 0.16 & 0.19 & 0.26 & 0.31 & 0.35 \\
\hline Mass areal accumulation $\left(\mathrm{kg} \mathrm{m}^{-2}\right)$ & Area as indicated & 10,956 & 11,987 & 13,086 & 13,222 & 16,087 & 18,972 & 14,726 & 17,134 & 19,586 \\
\hline Reef area cover & & $17.8 \%$ & & & & & & & & \\
\hline Average mass areal accumulation $\left[\mathrm{kg} \mathrm{m}^{-2}\right]$ & Barriers and shelf break & 20,245 & & & & & & & & \\
\hline Study area & & Noggin & Passage & & & & & & & \\
\hline Stratigraphic unit & & Unit 1 & postglacia & & & & & & & \\
\hline Geomorphic zone & & Inner+ & outer platf & & Terrace & + shelf-bre & & All bar & ier (inner & outer) \\
\hline Velocity scenario & & Min & Best est & Max & Min & Best est & Max & Min & Best est & Max \\
\hline Area $\left(\mathrm{km}^{2}\right)$ & Polygons digitized on geomorphic maps & 26 & 26 & 26 & 31 & 31 & 31 & 28 & 28 & 28 \\
\hline Total volume $\left(\mathrm{km}^{3}\right)$ & Calculations above $130 \mathrm{mbsl}$ & 0.05 & 0.06 & 0.06 & 0.23 & 0.23 & 0.24 & 0.21 & 0.25 & 0.28 \\
\hline Net carbonate volume $\left(\mathrm{km}^{3}\right)$ & Porosity $=35 \%$ & 0.03 & 0.04 & 0.04 & 0.15 & 0.15 & 0.16 & 0.14 & 0.16 & 0.18 \\
\hline Net carbonate mass $\left(\mathrm{Gt} \mathrm{CaCO}_{3}\right)$ & Density $=2930 \mathrm{~kg} \mathrm{~m}^{-3}$ & 0.10 & 0.11 & 0.11 & 0.44 & 0.45 & 0.46 & 0.40 & 0.47 & 0.54 \\
\hline Mass areal accumulation $\left(\mathrm{kg} \mathrm{m}^{-2}\right)$ & Area as indicated & 3817 & 3996 & 4342 & 14,146 & 14,509 & 14,886 & 14,186 & 16,758 & 19,365 \\
\hline Reef area cover & & $17.8 \%$ & & & & & & & & \\
\hline Average mass areal accumulation $\left[\mathrm{kg} \mathrm{m}^{-2}\right]$ & Barriers and shelf break & 20,245 & & & & & & & & \\
\hline
\end{tabular}

Table 2. Deposits at the control zones of Hydrographer's and Noggin Passages: total area, $\mathrm{CaCO}_{3}$ volume, $\mathrm{CaCO}_{3}$ mass and mass areal accumulation for different geomorphic zones ${ }^{47}$. Reef area ratio in the area comprised between the outer GBR fore-reef and the 130-m contour is similar in both sites. These figures are based on seismic three-dimensional reconstructions, geomorphic interpretations and core data ${ }^{30,34,40,47}$.

The timing of the shelf edge carbonate deposits. The timing of the $\mathrm{CaCO}_{3}$ deposits in the GBR, as approximated by the postglacial thickness method, suggests a possible concurrence between periods of maximum accumulation and rapid accretion rate (at ca. 12 and ca. $15.5 \mathrm{ka} \mathrm{BP}^{21}$ ). These were periods of high substrate availability and favourable environmental conditions for reef growth, as influenced by shelf physiography and sea-level rise ${ }^{21,49}$.

The postglacial thickness method cannot establish a precise chronology for $\mathrm{CaCO}_{3}$ mass accumulation at regional level, but it can provide a broad temporal trend. The periods of higher $\mathrm{CaCO}_{3}$ accumulation in the shelf edge (15.1-13.7 ka BP and 13.3-11.3 ka BP applying the $20 \mathrm{~m}$ maximum reef thickness assumption, Fig. 3b, Appendix 5) envelope at least two of the three episodes of increased slope of the atm- $\mathrm{CO}_{2}$ curve since the LGM (ca. 14.9-14.4 ka and ca. 13.0-11.5 ka BP ${ }^{67}$ ) (Fig. 3a,b). These periods of higher $\mathrm{CaCO}_{3}$ accumulation at the shelf edge also coincide with the episodes inferred by Ridgwell et al. ${ }^{5}$ in their models (17.0-13.8 ky and 12.3-11.2 ky $\mathrm{BP})$. These findings are consistent with a more recent analysis of all available postglacial vertical reef accretion 


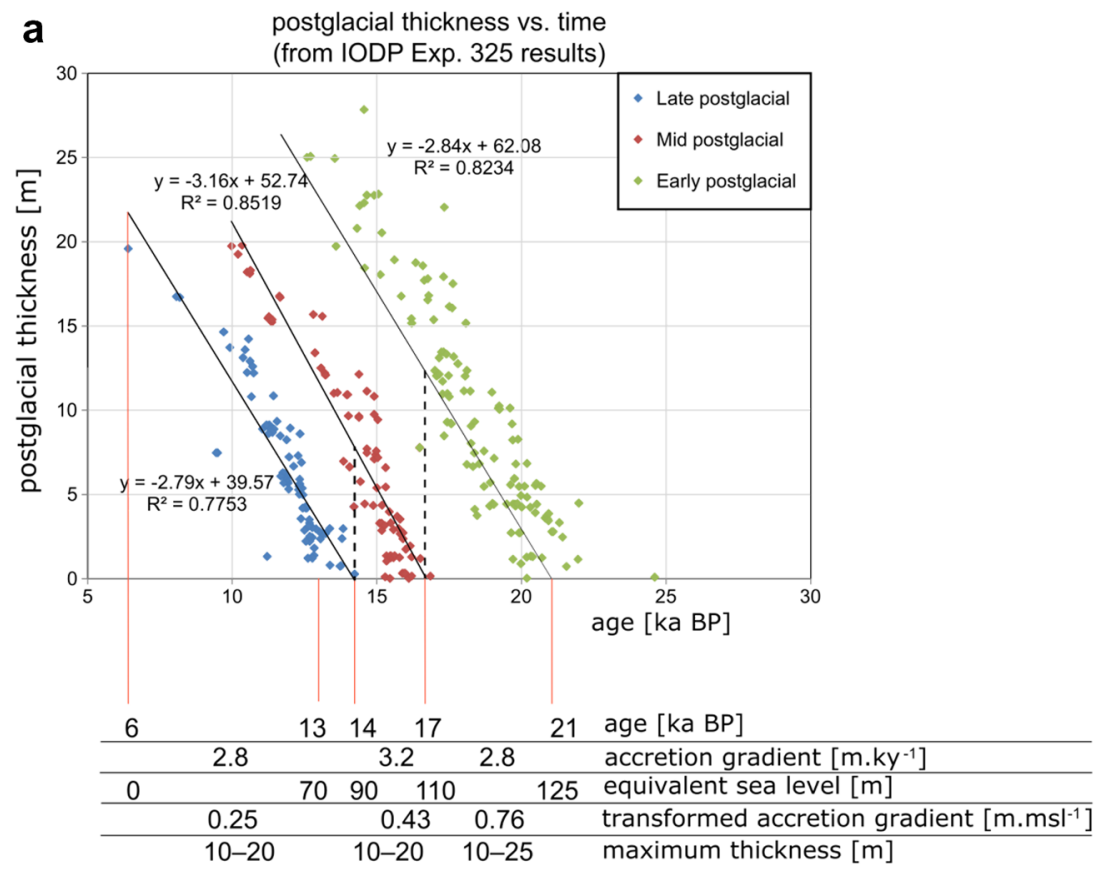

b

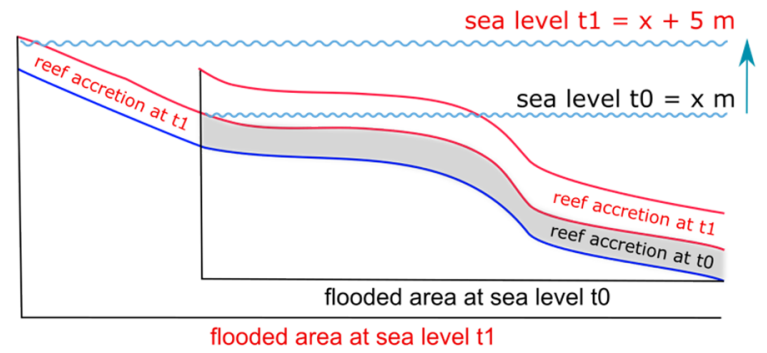

Thickness calculated using the transformed accretion gradient $=(\mathrm{m}$ reef $) .(\mathrm{m} \text { sea level rise })^{-1}$

Thickness limited by the maximum postglacial thickness trends

interpreted from drillcore samples chronology and thickness

Figure 4. Description of the postglacial thickness method for the calculation of reef deposits: (a) Vertical accretion rates (VA) and maximum accretion thickness were extracted from trends of postglacial thickness vs. geological age using the dated core samples from the IODP Exp. 325 (Webster et al. ${ }^{21}$, Appendix 3). These rates were converted into an equivalent rate relative to the past sea level increase (transformed accretion rate $\mathrm{VA}_{\mathrm{SL}}$ ) using a composite sea level curve (Fig. 5, Appendix 6). (b) The marine-flooded areas for each postglacial sea level $\left(\mathrm{FA}_{\mathrm{SL}}\right)^{49}$ were multiplied by the thickness corresponding to one sea level step, according to the previously calculated rate $\mathrm{VA}_{\mathrm{SL}}$. Flooded areas were not allowed to accumulate reef thickness beyond the maximum observed in (a). This can be represented as a thickness matrix (b) where each sea level step $(\mathrm{t} 0, \mathrm{t} 1, \ldots, \mathrm{tn})$ has a thickness vector applicable to the different flooded-area polygons (see Appendix 5 for full calculations).

data (including IODP Exp. 325), which shows rapid accretion rates (9.6 to more than $20 \mathrm{~mm} \mathrm{yr}^{-1}$ ) during these periods of higher $\mathrm{CaCO}_{3}$ accumulation (see Fig. $\mathrm{S} 6$ in Webster et al. ${ }^{21}$ ).

Our new estimates of postglacial, pre-Holocene carbonate deposits in the GBR (ca. $130 \mathrm{Gt} \mathrm{CaCO}_{3}$ ) and their global extrapolations ( $1500 \mathrm{Gt} \mathrm{CCO}_{3}$ ) suggest that pre-Holocene reef accretion is likely to be more relevant to the global $\mathrm{CaCO}_{3}$ budgets (hence in the global carbon cycle) than currently recognized. The impact of these deposits in the atm- $\mathrm{CO}_{2}$ should be assessed by global process-based carbon models that reflect the full complexity of the atmosphere-ocean-land biogeochemical cycles (Fig. 6).

\section{Conclusions}

1. The assembled dataset provides new constraints on Holocene reef deposits in the GBR: $751 \mathrm{Gt}^{\mathrm{CaCO}} \mathrm{C}_{3}$ as per our best estimate, varying between 520 and $1001 \mathrm{Gt} \mathrm{CaCO}_{3}$, distributed latitudinally with a strong correlation to the available shelf area. 


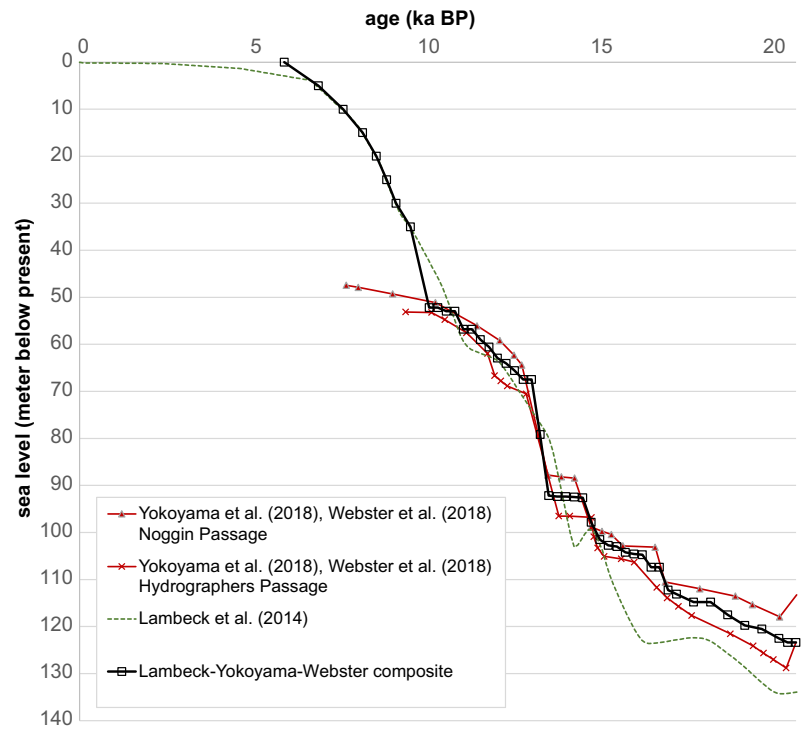

Figure 5. Composite sea level curve: constructed based on data in Lambeck et al. ${ }^{39}$ and Webster et al. ${ }^{21}$, Yokoyama et al. ${ }^{31}$. This sea-level curve was used to translate between past sea levels and geological time, allowing a possible temporal reconstruction of the $\mathrm{CaCO}_{3}$ deposition trends in the shelf edge of the GBR.

\begin{tabular}{|c|c|c|c|c|c|}
\hline \multirow{2}{*}{$\begin{array}{l}\text { Study } \\
\text { Feature }\end{array}$} & \multicolumn{5}{|l|}{ This study } \\
\hline & Global Holocene reefs & $\begin{array}{l}\text { Global shelf-edge reefs } \\
\text { (from GBR mass ratio) }\end{array}$ & $\begin{array}{l}\text { Global shelf-edge reefs } \\
\text { (from GBR area ratio) }\end{array}$ & $\begin{array}{l}\text { Global Halimeda mounds } \\
\text { (from GBR mass ratio) }\end{array}$ & Total postglacial $\mathrm{CaCO}_{3}$ \\
\hline $\begin{array}{l}\text { Dataset/observations/ } \\
\text { parameters }\end{array}$ & $\begin{array}{l}\text { Area in Spalding et al. }{ }^{56} \text {, } \\
\text { other parameters from this } \\
\text { study }\end{array}$ & $\begin{array}{l}\text { This study, shelf edge/ } \\
\text { Holocene mass adjustment } \\
\text { factor }=18 \%\end{array}$ & $\begin{array}{l}\text { This study, shelf edge/ } \\
\text { Holocene area adjustment } \\
\text { factor }=22 \%\end{array}$ & McNeil et al. ${ }^{27}$ & $\begin{array}{l}\text { Global Holocene }+ \text { shelf- } \\
\text { edge }+ \text { Halimeda mounds }\end{array}$ \\
\hline Timing (ka BP) & 8 to 0 & 19 to 10 & 19 to 10 & 8 to 0 & 19 to 0 \\
\hline Reef area $\left(\mathrm{km}^{2}\right)$ & 284,000 & 51,120 & 62,480 & 57,295 & 398,095 \\
\hline Porosity (\%) & 35 & 35 & 35 & 58 & $35-50$ \\
\hline Net $\mathrm{CaCO}_{3}$ volume $\left(\mathrm{km}^{3}\right)$ & 2769 & 498 & 609 & 202 & 3525 \\
\hline Density $\left(\mathrm{kg} \mathrm{m}^{-3}\right)$ & 2930 & 2930 & 2930 & 2930 & 2930 \\
\hline $\begin{array}{l}\text { Net } \mathrm{CaCO}_{3} \text { mass }(\mathrm{Gt} \\
\left.\mathrm{CaCO}_{3}\right)\end{array}$ & 8113 & 1460 & 1785 & 592 & 10,328 \\
\hline
\end{tabular}

Table 3. Global estimates of shallow-water reefs, shelf edge reefs and Halimeda bioherms as extrapolated from the proportions of the different features relative to the Holocene reefs of the GBR. Bold highlight the parameters applied in each case from which the rest of the values were derived.

2. The shelf-edge reefs of the GBR constitute an important portion of the postglacial shallow reef deposits: these (now) drowned reefs occupy an area of between 3000 and 12,000 $\mathrm{km}^{2}$, equivalent to ca. $10-45 \%$ of the total Holocene reef area in the GBR. In the GBR, these drowned reefs accumulated ca. $135 \mathrm{Gt}$ of reefal $\mathrm{CaCO}_{3}$, equivalent to ca. $18 \%$ of the mass estimated for the more recent Holocene deposits (best estimate). The latitudinal distribution of the shelf edge reefs is also strongly correlated to shelf availability.

3. By globally extrapolating the GBR constraints, we estimate a total accumulation of $8100 \mathrm{Gt}^{\mathrm{CaCO}} \mathrm{C}_{3}$ from Holocene reefs (best estimate), which is consistent with previously published estimates. Following from recently published results in the GBR, a minimum of ca. $590 \mathrm{Gt} \mathrm{CaCO}_{3}$ from Halimeda deposits should be added to the global Holocene $\mathrm{CaCO}_{3}$ mass, representing a 4-8\% increase in the budget.

4. Global extrapolations supported by recent surveys suggest that a significant proportion of postglacial, preHolocene shallow-water carbonate deposits can be attributed to now drowned postglacial reefs. These deposits of ca. $1500 \mathrm{Gt} \mathrm{CaCO}_{3}$ represent 16-20\% more mass in the global postglacial budget than if considering the Holocene reef deposits alone. Their inclusion in global carbon models could provide new constraints on postglacial global atmospheric and climate models. 


\begin{tabular}{|c|c|c|c|c|c|c|c|c|c|c|c|c|}
\hline Calculation & \multicolumn{12}{|c|}{ Total postglacial reefal (and Halimeda) $\mathrm{CaCO}_{3}$, including pre-Holocene drowned reefs } \\
\hline Features & \multicolumn{12}{|c|}{ Extrapolation of global Holocene + shelf-edge (average of mass and area adjustment factors) + Halimeda mounds (mass factor) } \\
\hline $\begin{array}{l}\text { Timing (ka } \\
\text { BP) }\end{array}$ & \multicolumn{12}{|l|}{19 to 0} \\
\hline $\begin{array}{l}\text { Average reef } \\
\text { thickness } \\
\text { (m) }\end{array}$ & \multicolumn{12}{|l|}{$8-15$} \\
\hline Porosity (\%) & \multicolumn{12}{|l|}{$35-50$} \\
\hline $\begin{array}{l}\text { Density } \\
\left(\mathrm{kg} \mathrm{m}^{-3}\right)\end{array}$ & \multicolumn{12}{|l|}{2930} \\
\hline Study & $\begin{array}{l}\text { Preferred } \\
\text { area } \\
\text { estimate } \\
\text { Spalding } \\
\text { et al. } .^{56}\end{array}$ & De Vooys ${ }^{64}$ & $\begin{array}{l}\text { Newell }^{73}- \\
\text { minimum }\end{array}$ & $\begin{array}{l}\text { Spalding } \\
\text { and } \\
\text { Grenfell }^{16}\end{array}$ & Vecsei $^{61}$ & $\begin{array}{l}\text { Ryan } \\
\text { et al }{ }^{15}- \\
\text { minimum }\end{array}$ & $\begin{array}{l}\text { Kleypas }^{58}- \\
\text { minimum }\end{array}$ & Smith ${ }^{28}$ & $\begin{array}{l}\text { Kleypas }^{58}- \\
\text { maximum }\end{array}$ & Milliman $^{74}$ & $\begin{array}{l}\mathrm{Newell}^{73}- \\
\text { maximum }\end{array}$ & Copper $^{65}$ \\
\hline $\begin{array}{l}\text { Reef area } \\
\left(\mathrm{km}^{2}\right)\end{array}$ & 398,095 & 156,995 & 210,261 & 357,445 & 483,601 & 700,872 & 818,618 & 864,876 & $1,045,700$ & $2,018,510$ & $2,102,615$ & $2,102,615$ \\
\hline $\begin{array}{l}\text { Total } \\
\text { volume }>130 \\
\text { mbsl }\left(\mathrm{km}^{3}\right)\end{array}$ & 5593 & 2206 & 2954 & 5022 & 6795 & 9847 & 11,502 & 12,152 & 14,692 & 28,360 & 29,542 & 29,542 \\
\hline $\begin{array}{l}\text { Net } \mathrm{CaCO}_{3} \\
\text { volume } \\
\left(\mathrm{km}^{3}\right)\end{array}$ & 3525 & 1390 & 1862 & 3165 & 4282 & 6206 & 7248 & 7658 & 9259 & 17,873 & 18,618 & 18,618 \\
\hline $\begin{array}{l}\mathrm{Net} \mathrm{CaCO}_{3} \\
\text { mass }(\mathrm{Gt} \\
\left.\mathrm{CaCO}_{3}\right)\end{array}$ & 10,328 & 4073 & 5455 & 9273 & 12,546 & 18,183 & 21,238 & 22,438 & 27,129 & 52,368 & 54,550 & 54,550 \\
\hline $\begin{array}{l}\mathrm{Net} \mathrm{CaCO}_{3} \\
\text { accumula- } \\
\text { tion rate (Gt } \\
\left.\mathrm{CaCO}_{3} \mathrm{y}^{-1}\right)\end{array}$ & 0.6 & 0.2 & 0.3 & 0.5 & 0.7 & 1.1 & 1.2 & 1.3 & 1.6 & 3.1 & 3.2 & 3.2 \\
\hline $\begin{array}{l}\text { Mass areal } \\
\text { accumula- } \\
\text { tion }\left(\mathrm{kg} \mathrm{m}^{-2}\right)\end{array}$ & 25,944 & 25,944 & 25,944 & 25,944 & 25,944 & 25,944 & 25,944 & 25,944 & 25,944 & 25,944 & 25,944 & 25,944 \\
\hline
\end{tabular}

Table 4. Extrapolations of global $\mathrm{CaCO}_{3}$ deposits applying the parameters of this study (Table 3) but using the broad range of past global reef area estimates shown in Table 5.

\begin{tabular}{|c|c|}
\hline \multicolumn{2}{|c|}{$\begin{array}{l}\text { Global estimates of present-day } \\
\text { coral-reef area }\end{array}$} \\
\hline \multicolumn{2}{|l|}{$\left(\times 10^{3} \mathrm{~km}^{2}\right)$} \\
\hline Newell $^{73}$ & $150-1500$ \\
\hline Milliman $^{74}$ & 1440 \\
\hline Smith $^{28}$ & 617 \\
\hline De Vooys ${ }^{64}$ & 112 \\
\hline Copper $^{65}$ & 1500 \\
\hline Kleypas $^{58}$ & $584-746$ \\
\hline Spalding and Grenfell ${ }^{16}$ & 255 \\
\hline Ryan et al. ${ }^{15}$ & $>500$ \\
\hline Spalding et al. ${ }^{56}$ & 284 \\
\hline Vecsei $^{61}$ & 345 \\
\hline
\end{tabular}

Table 5. Global estimates of present-day coral reef area according to different authors.

5. Our results support a more prominent role in the postglacial carbon cycle for pre-Holocene shallow-water coral reefs. Significantly, the timing of higher $\mathrm{CaCO}_{3}$ deposition in the GBR is broadly coeval with two distinct episodes of postglacial atm- $\mathrm{CO}_{2}$ increase (ca. $14.9-14.4 \mathrm{ka}$ and ca. $13.0-11.5 \mathrm{ka} \mathrm{BP}{ }^{67}$ ). Any causal relationship must be confirmed by more complex, process-based models of the global carbon and other biogeochemical cycles and global surveys of drowned reefs and reef areas.

\section{Methods}

We estimated the carbonate volume in the GBR for: (1) early postglacial reef deposits (21-10 ka); and (2) Holocene reef deposits. We also attempted a global extrapolation of these carbonate deposits based on these new and well-constrained regional GBR estimates.

Data were available across the whole GBR: bathymetry at $\sim 100 \mathrm{~m}$ resolution ${ }^{57}$, GIS layers with reef locations and extensions ${ }^{50}$; previous GBR Holocene drill cores (see Appendix 1 for summary and Hopley et al ${ }^{68}$ for data 


\begin{tabular}{|c|c|c|c|c|c|c|c|}
\hline Study & Kinsey and Hopley ${ }^{55}$ & Milliman and Droxler ${ }^{12}$ & \multicolumn{2}{|c|}{ Ryan et al. ${ }^{15}$} & $\operatorname{Rees}^{13}$ & Hillis $\left({ }^{75}\right)$ & Hillis $\left({ }^{75}\right)$ \\
\hline Feature & Holocene reefs & Holocene reefs & \multicolumn{2}{|c|}{ Holocene reefs } & Holocene reefs & $\begin{array}{l}\text { Present-day Halimeda } \\
\text { bioherms }\end{array}$ & $\begin{array}{l}\text { Total present-day } \\
\text { Halimeda production }\end{array}$ \\
\hline Dataset/observations & $\begin{array}{l}\text { As reported in Kayanne } \\
(1992)\end{array}$ & $\begin{array}{l}\text { Productivity (here } \\
\text { called accumulation } \\
\text { rate) estimated for the } \\
\text { present-day reefs }\end{array}$ & \multicolumn{2}{|c|}{ 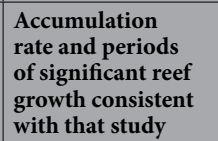 } & $\begin{array}{l}\text { Global reef area in } \\
\text { Spalding et al. (2001), } \\
\text { other parameters in } \\
\text { Rees (2006) }\end{array}$ & $\begin{array}{l}\text { Global Halimeda } \\
\text { bioherms area and } \\
\text { production from } \\
\text { present-day cover and } \\
\text { accretion rates }\end{array}$ & $\begin{array}{l}\text { Global Halimeda } \\
\text { production from } \\
\text { present-day cover and } \\
\text { accretion rates }\end{array}$ \\
\hline Timing (ka BP) & 8 to 0 & 8 to 0 & 8 to 0 & 8 to 4 & 10 to 0 & 8 to 0 & 8 to 0 \\
\hline Reef area $\left(\mathrm{km}^{2}\right)$ & 620,000 & 600,000 & 500,000 & 500,000 & 284,000 & 50,000 & 850,000 \\
\hline $\begin{array}{l}\text { Average reef thickness } \\
\text { (m) }\end{array}$ & 10 & 15 & 14 & 7 & 19 & 4 & 1 \\
\hline $\begin{array}{l}\text { Total volume }>130 \mathrm{mbsl} \\
\left(\mathrm{km}^{3}\right)\end{array}$ & 6159 & 3826 & 7197 & 3599 & 5497 & 205 & 546 \\
\hline Porosity (\%) & 50 & 50 & 50 & 50 & 50 & 50 & 50 \\
\hline $\begin{array}{l}\mathrm{Net} \mathrm{CaCO}_{3} \text { volume } \\
\left(\mathrm{km}^{3}\right)\end{array}$ & 3080 & 1913 & 3599 & 1799 & 2748 & 410 & 1092 \\
\hline Density $\left(\mathrm{kg} \mathrm{m}^{-3}\right)$ & 2890 & 2930 & 2890 & 2890 & 2900 & 2930 & 2930 \\
\hline $\begin{array}{l}\text { Net } \mathrm{CaCO}_{3} \text { mass }(\mathrm{Gt} \\
\left.\mathrm{CaCO}_{3}\right)\end{array}$ & 8900 & 5605 & 10,400 & 5200 & 7970 & 1200 & 3200 \\
\hline $\begin{array}{l}\text { Net } \mathrm{CaCO}_{3} \text { accumula- } \\
\text { tion rate }\left(\mathrm{Gt} \mathrm{CaCO}_{3} \mathrm{y}^{-1}\right)\end{array}$ & 0.9 & 0.7 & 1.3 & 1.3 & 0.8 & 0.2 & 0.4 \\
\hline $\begin{array}{l}\text { Mass areal accumulation } \\
\left(\mathrm{kg} \mathrm{m}^{-2}\right)\end{array}$ & 14,355 & 9341 & 20,800 & 10,400 & 28,063 & 24,000 & 3765 \\
\hline
\end{tabular}

Table 6. Global estimates of $\mathrm{CaCO}_{3}$ mass and/or accumulation rate of present-day shallow-water reefs, Holocene reefs and Halimeda bioherms according to different authors. To establish a comparison among new and past estimates, some of the values were calculated using the parameters highlighted in bold.

sources). We distinguished the areas at the shelf edge (defined here between the modern outer GBR reef front and the $130 \mathrm{~m}$ isobath) from the other areas of the shelf and extracted the corresponding bathymetric subset.

More locally, data were available for two densely surveyed control zones at the shelf edge (Noggin Passage and Hydrographers Passage; Fig. 2) where reef volumetrics and mass accumulation were estimated with a high degree of confidence for Quaternary reefs. This was possible due to: (1) availability of seismic-derived three-dimensional reconstructions of the reef patterns and volumetrics ${ }^{40,47} ;(2)$ extensive and precise chronologic database $(>580$ published U-Th and ${ }^{14} \mathrm{C}$ ages), lithological and petrophysical properties directly measured from the IODP Exp. 325 drill holes and cores ${ }^{30,31}$; (3) high-resolution $\left(5 \mathrm{~m}\right.$ ) bathymetric coverage in these sites ${ }^{34}$; and (4) extensive knowledge on the development history and age structure of the shelf-edge reef system ${ }^{21}$.

For all calculations, we assumed:

- Aragonite density $\left(\rho_{\mathrm{A}}\right)=2930 \mathrm{~kg} \mathrm{~m}^{-3}$

- Reef formation porosity $\left(\Phi_{\mathrm{R}}\right)=35 \%^{30}$.

To estimate the postglacial Pleistocene carbonate deposits, we first produced the following input for both of the estimation methods we applied:

- Reef area ratio [\%] at the shelf-edge control zones: the percentage of reef formation area extension compared to total shelf edge area (Fig. 2). This value was obtained by digitising the area occupied by reef banks and comparing it to the total shelf-edge area. The identification of the banks was supported by the bathymetry, backscatter, seismic and GIS data ${ }^{34,40,47,50}$. The results of both control zones were averaged and rounded to the nearest ten to obtain a best estimate of $20 \%$. To capture plausible uncertainties, arbitrary minimum and maximum values were set: a minimum reef area ratio of $10 \%$ equivalent to the proportion of Holocene reef area ratio in the whole GBR shelf; and a maximum value of twice the best estimate.

- Formation volume $\left[\mathrm{m}^{3}\right]$ at the shelf-edge control zones: the volume contained between the present day, seafloor bathymetry and the antecedent basal substrate (Reflector 1) as obtained from the seismic interpretations ${ }^{40,47}$. The three different velocity scenarios (1700-3300 $\mathrm{m} \mathrm{s}^{-1}$ ) to convert from seismic time to true depth ${ }^{47}$ were considered to obtain a minimum, best estimate, and maximum values for each set of maps.

- Mass areal accumulation (MAA) $\left[\mathrm{kg} \mathrm{m}^{-2}\right]$ at the shelf-edge control zones: these values were calculated for each control zone by transforming each formation volume estimate to carbonate mass $\left(\mathrm{CaCO}_{3}\right.$ mass $=$ formation volume $\left.\times \rho_{\mathrm{A}} \times\left(1-\Phi_{\mathrm{R}}\right)\right)$ and subsequently dividing the mass by the total shelf edge area of the control zones $\left(\mathrm{MAA}=\right.$ mass $\left.\cdot[\text { shelf edge area }]^{-1}\right)$. The calculations were also applied for each of the main geomorphic zones ${ }^{47}$ : inner barrier, outer barrier, terrace and shelf break combined, and inner and outer platforms combined. Three values were applied to account for plausible minimum, best and maximum scenarios: the average MAA value of all reef locations, and the minimum and the maximum MAA value in any reef location (Table 2). 


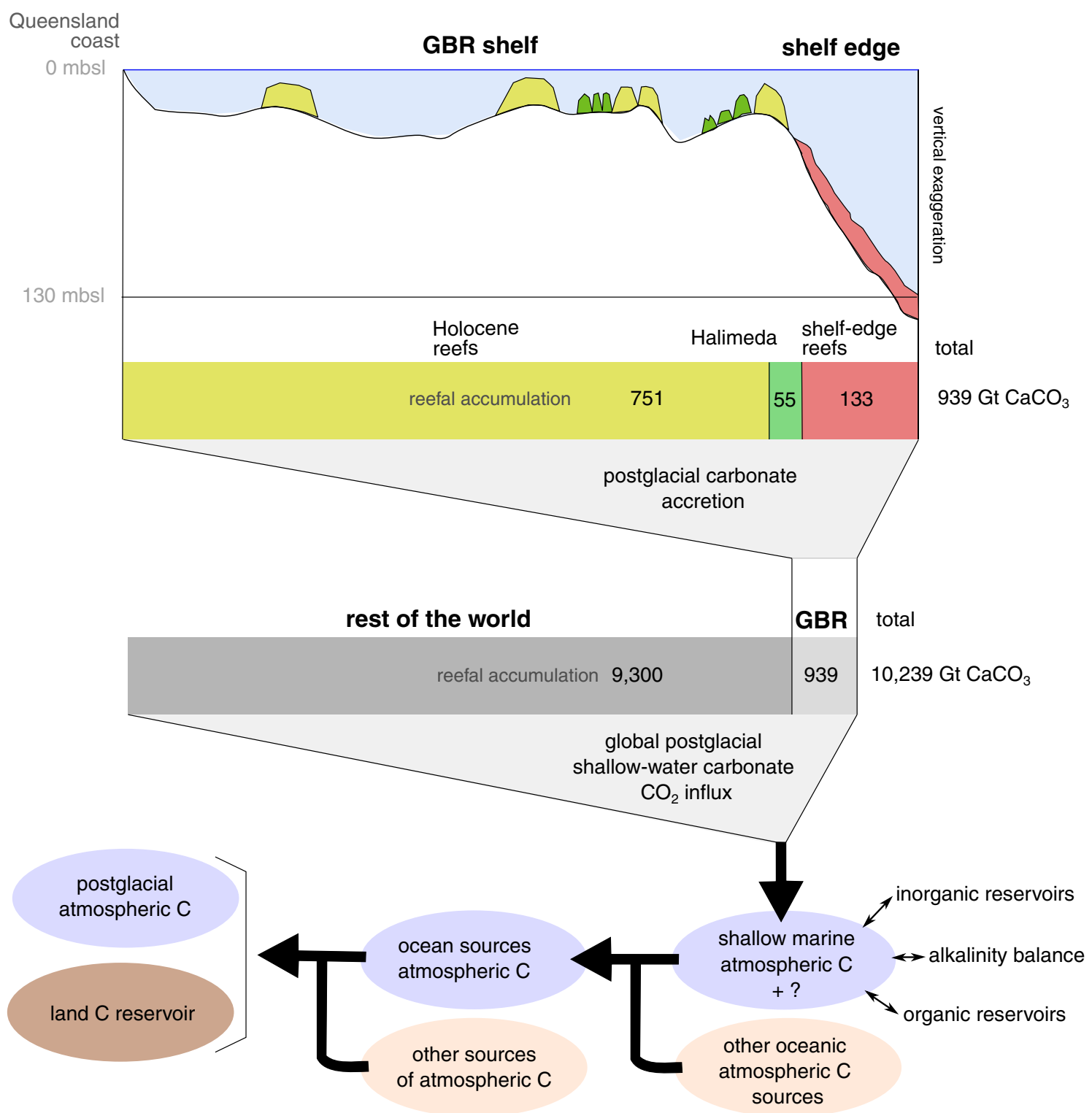

Figure 6. Summary of $\mathrm{CaCO}_{3}$ volumetrics by formation, and comparison between global and GBR regional deposits. The postglacial reefs and Halimeda deposits participate in the global carbon cycle by changing the alkalinity of the shallow ocean, affecting $\mathrm{CO}_{2}$ solubility and eventually provoking an influx of $\mathrm{CO}_{2}$ to the atmosphere.

- Vertical accretion rate $\left[\mathrm{m} \mathrm{ky}^{-1}\right]$ at the shelf-edge control zones: the glacial-postglacial boundary recognized in the cores and the radiometric ages measured in the Exp. 325 core samples $^{21}$ allowed the estimation of the vertical accretion gradients $\left(\mathrm{m} \mathrm{ky}^{-1}\right)$ for the entire postglacial Pleistocene time period (21-10 ka) (Fig. 4, Appendix 3).

- Maximum cumulative thickness [m], at the shelf-edge control zones: we estimated the maximum reef thickness for the different stages of postglacial shelfedge reef development from the vertical accretion rate plots. For one of the estimation methods (postglacial thickness method), this became a necessary constraint to avoid unrealistic cumulative reef thickness as sea-level rise progressed (Fig. 4).

- Postglacial shelf margin flooded area, for each $5 \mathrm{~m}$ increment $\left[\mathrm{km}^{2}\right]$ : we calculated the marine cover corresponding to past postglacial sea levels by performing surface operations in GIS software. We used the $100 \mathrm{~m}$ bathymetric dataset ${ }^{57}$ comprising the whole GBR, from northern Fraser Island to north of Cape York. We extracted the shelf-edge areas defining them as the areas between the outer GBR and the $130 \mathrm{~m}$ depth contour (Appendix 7). The bathymetric surface was sliced into thirty-three $50 \mathrm{~km}$ wide latitudinal zones after Hinestrosa et al. ${ }^{49}$. Each of the zones was flooded using sea levels ranging from 130 to $0 \mathrm{~m}$ in $5 \mathrm{~m}$ steps to obtain marine-flooded area in $\mathrm{km}^{2}$. To represent the timing of the flooded area at each sea-level increment, we applied a composite relative sea-level curve to the results in Hinestrosa et al. ${ }^{49}$ (Fig. 5, Appendix 6). The relative sea level was reconstructed from data in Lambeck et al. ${ }^{39}$, Yokoyama et al. ${ }^{31}$ and Webster et al. ${ }^{21}$ The 
flooded areas in each $5 \mathrm{~m}$ step were then matched to geological time according to sea levels represented in the relative sea-level curve $(125-0 \mathrm{~m})$.

The Holocene reef $\mathrm{CaCO}_{3}$ accumulation was calculated using the following parameters:

- Reef area $\left[\mathrm{m}^{2}\right]$ from the Queensland coast to the outer GBR: the reef area was estimated from GIS layers containing polygons representing the outline of the Holocene reefs (Figs. 1 and 2, Supplementary data). This layer was obtained from a detailed interpretation of recently available satellite images and shallow bathymetry ${ }^{29,50}$. Continental islands and reefs belonging to the shelf edge were excluded to better approximate Holocene reef area. These features were sliced into thirty-three latitudinal zones $50 \mathrm{~km}$ wide to capture the latitudinal variations (Figs. 1, 3e). We assumed that the reef area polygons represent the main reef and bioclastic deposits directly related to Holocene reef growth. However, unaccounted fore- and back-reef aprons may constitute a significant portion of the reefal carbonate volume $e^{15,51}$. There are of course, uncertainties inherent to the original sources (satellite imagery and bathymetric mapping) and their interpretation, which could result in an overestimation of the reef area in the northern GBR, the under or overestimation of the extent of the bioclastic cover, or the misrepresentation of some locations as Holocene reefs when they might be older Pleistocene outcrops ${ }^{50}$.

- Reef thickness from Holocene GBR drill cores [m]: a dataset of Holocene reef thicknesses was used to estimate minimum, average and maximum thickness values for the Holocene reef thickness ${ }^{68}$ (Appendix 1). These drilling results show a Holocene reef veneer varying from less than $5 \mathrm{~m}$ to more than $25 \mathrm{~m}$ depending on location, with the thickest reefs recorded at around $18^{\circ} \mathrm{S}$.

- Halimeda deposits mass [ $\left.\mathrm{Gt}_{\mathrm{CaCO}}\right]$ : we used the most up-to-date estimate for Halimeda accumulations in the $\mathrm{GBR}^{27}$ and considered these values in our Holocene totals (Table 1).

For the global extrapolations, we also considered the following parameters:

- Global reef area $\left[\mathrm{km}^{2}\right]$ : values for global reef area were extracted from the observational study by Spalding et al. ${ }^{56}$, but other past values (Table 5) were considered for comparison (Table 4).

- Area adjustment factor [\%]: defined as the ratio of shelf-edge reef area to the Holocene reef area. According to our estimates in the GBR, this corresponds to $22 \%$ (Table 1).

- Mass adjustment factor [\%]: defined as the ratio of $\mathrm{CaCO}_{3}$ mass at the shelf edge to the $\mathrm{CaCO}_{3}$ mass of the Holocene reef. According to our estimates in the GBR, this corresponds to $18 \%$ (Table 1).

Postglacial pleistocene carbonate deposits. We followed two approaches. The postglacial-thickness method attempts to reconstruct the temporal evolution of the reef accretion by considering the change in flooded area since the LGM. The mass areal accumulation method does not consider the change in marine flooding area and outputs the cumulative postglacial volume and $\mathrm{CaCO}_{3}$ mass.

Shelf edge carbonate deposits-mass areal accumulation method. The mass areal accumulation method is based on one key assumption: that the reef area ratio and mass areal accumulation variables calculated locally at the Exp. 325 control zones are valid along the entire extension of the shelf edge.

For each latitudinal zone in the shelf edge bathymetric subset, the maximum highstand flooded area (FA) was multiplied by the reef area ratio (RAR) and mass areal accumulation (MAA) values to obtain $\mathrm{CaCO}_{3}$ accumulation values in the GBR shelf margin (Table 1).

- Pleistocene $\mathrm{CaCO}_{3}$ mass $=\mathrm{FA} \times \mathrm{RAR} \times \mathrm{MAA}$

Shelf edge carbonate deposits-postglacial-thickness method. The postglacial-thickness method relies on the assumption that reef area ratio, vertical accretion rate and maximum cumulative thickness values observed in the control zones can be extended to other locations along the GBR shelf edge. It also assumes that the parameters remain constant through time. By considering accretion rates and maximum thickness, this method allows us to approximate the temporal evolution of the shelf-edge deposits.

Firstly, the vertical accretion rate for each reef development episode (Webster et al., 2018) was converted to an equivalent rate relative to past sea-level steps. This allowed us to associate an incremental reef thickness to each of the $5 \mathrm{~m}$ sea-level steps considered. Conversion from geological age to equivalent sea level was performed using a simplified relative sea-level curve based on Lambeck et al. ${ }^{39}$ for ages more recent than $10 \mathrm{ka} \mathrm{BP}$, and based on Webster et al. ${ }^{21}$, Yokoyama et al. ${ }^{31}$ for ages before $10 \mathrm{ka} \mathrm{BP}$ (Fig. 5, Appendix 6).

To obtain an estimate of reef volume at each sea-level step, we first estimated reef thickness by multiplying the converted postglacial vertical accretion rate $\left(\mathrm{VA}_{\mathrm{SL}}\right)$ by each sea-level step $(5 \mathrm{~m})$. Subsequently, the product of this thickness and the flooded area at each flooding stage $\left(\mathrm{FA}_{\mathrm{SL}}\right)$ gave us the formation volume for each one of the thirty-three latitudinal zones and for each sea-level step. The volume was scaled down by the reef area ratio $(R A R)$ values (minimum, best estimate, maximum; Table 1) to obtain a measure representative of the shelf edge geomorphology as observed at the control zones. In the calculations, each flooded area had a cap on cumulative reef thickness: the maximum cumulative thickness (Fig. 4). The $\mathrm{CaCO}_{3}$ accumulated mass for each sea-level increase was obtained by multiplying these volumes by formation net volume $\left(1-\Phi_{R}\right)$ and density $\left(\rho_{\mathrm{A}}\right)$ :

Pleistocene $\mathrm{CaCO}_{3}$ mass for each sea level (SL) between 130 and $0 \mathrm{~m}$ : 
- Incremental reef volume $=V A_{S L} \times 5 m \times F A_{S L} \times R A R$

- Incremental $\mathrm{CaCO}_{3}$ mass = Incremental reef volume $\times \rho_{\mathrm{A}} \times\left(1-\Phi_{R}\right)$

- Cumulative $\mathrm{CaCO}_{3}$ mass $=\Sigma$ (Incremental $\mathrm{CaCO}_{3}$ mass)

Holocene veneer carbonate accumulation estimates. To obtain values of total $\mathrm{CaCO}_{3}$ mass of Holocene carbonate in the GBR, the reef thickness (RT) values were multiplied by the reef area (RA) to obtain cumulative Holocene carbonate volumes for the GBR as a whole and for each one of the thirty-three latitudinal zones (Fig. 1). Mass values were obtained by multiplying these volumes by formation net volume (1- $\left.\Phi_{R}\right)$ and density $\left(\rho_{\mathrm{A}}\right)$ (Table 1$)$, as summarised below:

- Holocene reef volume $=R A \times R T$

- Holocene reef $\mathrm{CaCO}_{3}$ mass $=$ Holocene reef volume $\times \rho_{A} \times\left(1-\Phi_{R}\right)$

Global estimates. We consider the contribution of drowned postglacial reefs in global $\mathrm{CaCO}_{3}$ budgets. We extrapolated the estimates and trends of $\mathrm{CaCO}_{3}$ deposits for the GBR to the entire globe. We used published estimates of global reef area and parameters ground-truthed by the GBR dataset. The global reef area $\left(\mathrm{RA}_{\mathrm{GLOBAL}}\right)$ was multiplied by average thickness (RT) and petrophysical parameters $\left(\rho_{\mathrm{A}}, \Phi_{\mathrm{R}}\right)$ to obtain global postglacial $\mathrm{CaCO}_{3}$ deposits.

We accounted for the drowned Pleistocene reefs by applying two assumptions in our calculations to obtain two equivalent results.

- Assumption 1: on average, the proportion of postglacial drowned reefs areas corresponding to a given Holocene reef area is similar across all reef provinces. We expressed this assumption as a ratio of shelf margin area to total Holocene reef area, the area adjustment factor $\left(\mathrm{AF}_{\mathrm{A}}\right)$,

- Assumption 2: on average, the postglacial drowned reefs mass corresponding to a given Holocene reef mass is similar across all reef provinces. We expressed this assumption as a ratio of shelf margin $\mathrm{CaCO}_{3}$ mass to Holocene reef $\mathrm{CaCO}_{3}$ mass, the mass adjustment factor $\left(\mathrm{AF}_{\mathrm{M}}\right)$.

The values for global reef area $\left(R A_{\text {global }}\right)$ have a large range of uncertainty as demonstrated by the range of values proposed by different authors (Table 5 ). We consider those by Spalding et al. ${ }^{56}$ more accurate given the ground-truthing datasets. The factors that we applied on the global area $\left(A F_{A}, A F_{M}\right)$ have a large associated uncertainty: despite the evidence for drowned reefs in other geographical locations, the exact global extension and morphology of drowned reefs is not well constrained. Other carbonate provinces might differ in morphology, in accretion trends and in the proportion of Pleistocene reefs present along their margins compared to the more recent Holocene deposits of those provinces.

- Global postglacial $\mathrm{CaCO}_{3}$ accumulation $=R A_{\text {global }} \times R T_{G B R} \times \rho_{A} \times\left(1-\Phi_{R}\right)$

- Assumption 1:

- Area-adjusted global postglacial $\mathrm{CaCO}_{3}$ mass $=R A_{\text {global }} \times R T_{G B R} \times \rho_{\mathrm{A}} \times\left(1-\Phi_{R}\right) \times\left(1+A F_{A}\right)$

- Assumption 2:

- Mass-adjusted global postglacial $\mathrm{CaCO}_{3}$ mass $=R A_{\text {global }} \times R T_{G B R} \times \rho_{\mathrm{A}} \times\left(1-\Phi_{R}\right) \times\left(1+A F_{M}\right)$.

On $\mathrm{CO}_{2}$ and total $\mathrm{C}$ estimates. The chemical equilibrium of the shallow ocean is complex, with the concentration of the main inorganic carbon species $\left(\mathrm{CO}_{2}, \mathrm{HCO}_{3}{ }^{-}, \mathrm{CO}_{3}{ }^{-}\right)$varying according to temperature, salinity and pressure ${ }^{69,70}$.

According to the coral reef hypothesis ${ }^{6,71}$, reefal $\mathrm{CaCO}_{3}$ accretion provides $\mathrm{CO}_{2}$ to the environment by increasing the concentration of $\mathrm{CO}_{2}$ in the ocean water. The equivalent $\mathrm{CO}_{2}$ and $\mathrm{C}$ mass based on the stoichiometry of the chemical reaction: $\mathrm{Ca}^{2+}+2 \mathrm{HCO}_{3}{ }^{-}==>\mathrm{CaCO}_{3}+\mathrm{CO}_{2}+\mathrm{H}_{2} \mathrm{O}^{6,66}$ gives an incomplete picture because the exact proportion would depend on physical conditions that would have varied during the postglacial period. Experimentally, it has been demonstrated that for each mole of $\mathrm{CaCO}_{3}$ precipitated in seawater only a fraction of a mole of $\mathrm{CO}_{2}$ is fed to the surrounding waters due to the buffering effect of marine water ${ }^{8,72}$. It is then unclear how much of this carbon is released into the atmosphere, especially at centennial timescales ${ }^{66,72}$. The pathways for the released $\mathrm{CO}_{2}$ molecules are varied-they can be absorbed into inorganic or organic marine carbon cycles, or they can also be transferred into the atmosphere by the balancing of the partial pressure of $\mathrm{CO}_{2}$. We have not attempted to quantify the corresponding postglacial $\mathrm{CO}_{2}$ contribution to the surrounding waters and to the atmosphere. This would require more complex carbon models which are beyond the scope of this study.

Received: 15 April 2021; Accepted: 22 December 2021

Published online: 18 January 2022

\section{References}

1. Ciais, P. et al. Climate change 2013: The Physical Science Basis. Contribution of Working Group I to the Fifth Assessment Report of the Intergovernmental Panel on Climate Change. (Cambridge, United Kingdom, 2013).

2. O’Neill, C. M., Hogg, A. M., Ellwood, M. J., Opdyke, B. N. \& Eggins, S. M. Sequential changes in ocean circulation and biological export productivity during the last glacial-interglacial cycle: A model-data study. Climate Past 17, 171-201. https://doi.org/10. 5194/cp-17-171-2021 (2021). 
3. Brovkin, V. et al. Comparative carbon cycle dynamics of the present and last interglacial. Quatern. Sci. Rev. 137, 15-32. https:// doi.org/10.1016/j.quascirev.2016.01.028 (2016).

4. Kohfeld, K. E. \& Ridgwell, A. Glacial-interglacial variability in atmospheric $\mathrm{CO}_{2}$. Surf. Ocean-lower Atmos. Process. 187, 251-286. https://doi.org/10.1029/2008GM000845 (2009).

5. Ridgwell, A. J., Watson, A. J., Maslin, M. A. \& Kaplan, J. O. Implications of coral reef buildup for the controls on atmospheric $\mathrm{CO}_{2}$ since the last glacial maximum. Paleoceanography 18, 7-1. https://doi.org/10.1029/2003PA000893 (2003).

6. Berger, W. H. Deglacial $\mathrm{CO}_{2}$ buildup: Contraints on the coral reefs. Palaeogeogr. Palaeoclimatol. Palaeoecol. 40, 235-253. https:// doi.org/10.1016/0031-0182(82)90092-X (1982).

7. Opdyke, B. N. \& Walker, J. C. G. Return of the coral reef hypothesis: Basin to shelf partitioning of $\mathrm{CaCO}_{3}$ and its effect on atmospheric $\mathrm{CO}_{2}$. Geology 20, 733-736. https://doi.org/10.1130/0091-7613(1992)020\%3c0733:Rotcrh\%3e2.3.Co;2 (1992).

8. Ware, J. R., Smith, S. V. \& Reaka-Kudla, M. L. Coral reefs: Sources or sinks of atmospheric $\mathrm{CO}_{2}$ ?. Coral Reefs 11, 127-130. https:// doi.org/10.1007/BF00255465 (1992).

9. Broecker, W. S. \& Henderson, G. M. The sequence of events surrounding Termination II and their implications for the cause of glacial-interglacial $\mathrm{CO}_{2}$ changes. Paleoceanography 13, 352-364. https://doi.org/10.1029/98pa00920 (1998).

10. Sowers, T., Bender, M., Raynaud, D., Korotkevich, Y. S. \& Orchardo, J. The $\delta^{18} \mathrm{O}$ of atmospheric $\mathrm{O}_{2}$ from air inclusions in the Vostok Ice Core: Timing of $\mathrm{CO}_{2}$ and ice volume changes during the penultimate deglaciation. Paleoceanography 6, 679-696. https://doi. org/10.1029/91pa02023 (1991).

11. Shakun, J. D. et al. Global warming preceded by increasing carbon dioxide concentrations during the last deglaciation. Nature 484, 49-54. https://doi.org/10.1038/nature10915 (2012).

12. Milliman, J. D. \& Droxler, A. W. Neritic and pelagic carbonate sedimentation in the marine environment: Ignorance is not bliss. Geol. Rundsch. 85, 496-504. https://doi.org/10.1007/BF02369004 (1996).

13. Rees, S. A. Coral reefs of the Indo-Pacific and changes in global Holocene climate $\mathrm{PhD}$ thesis, University of Southampton (2006).

14. Rees, S. A., Opdyke, B. N., Wilson, P. A. \& Fifield, L. K. Coral reef sedimentation on Rodrigues and the Western Indian Ocean and its impact on the carbon cycle. Philos. Trans. R. Soc. Math. Phys. Eng. Sci. 363, 101-120. https://doi.org/10.1098/rsta.2004.1481 (2005).

15. Ryan, D. A., Opdyke, B. N. \& Jell, J. S. Holocene sediments of Wistari Reef: towards a global quantification of coral reef related neritic sedimentation in the Holocene. Palaeogeogr. Palaeoclimatol. Palaeoecol. 175, 173-184. https://doi.org/10.1016/S00310182(01)00370-4 (2001).

16. Spalding, M. D. \& Grenfell, A. M. New estimate of global and regional coral areas. Coral Reefs 16, 225-230. https://doi.org/10. $1007 / 5003380050078$ (1997).

17. Brovkin, V. et al. Carbon cycle, vegetation, and climate dynamics in the Holocene: Experiments with the CLIMBER-2 model. Global Biogeochem. Cycles 16, 86-1-86-20. https://doi.org/10.1029/2001gb001662 (2002).

18. Köhler, P. \& Munhoven, G. Late Pleistocene carbon cycle revisited by considering solid Earth processes. Paleoceanogr. Paleoclimatol. https://doi.org/10.1029/2020PA004020 (2020).

19. Husson, L. et al. Reef carbonate productivity during quaternary sea level oscillations. Geochem. Geophys. Geosyst. 19, 1148-1164. https://doi.org/10.1002/2017gc007335 (2018).

20. Montaggioni, L. F. History of Indo-Pacific coral reef systems since the last glaciation: Development patterns and controlling factors. Earth Sci. Rev. 71, 1. https://doi.org/10.1016/j.earscirev.2005.01.002 (2005).

21. Webster, J. M. et al. Response of the Great Barrier Reef to sea-level and environmental changes over the past 30,000 years. Nat. Geosci. 11, 426-432. https://doi.org/10.1038/s41561-018-0127-3 (2018).

22. Camoin, G. F. et al. Reef response to sea-level and environmental changes during the last deglaciation: Integrated Ocean Drilling Program Expedition 310, Tahiti Sea Level. Geology 40, 643-646. https://doi.org/10.1130/g32057.1 (2012).

23. Woodroffe, C. D. \& Webster, J. M. Coral reefs and sea-level change. Mar. Geol. 352, 248-267. https://doi.org/10.1016/j.margeo. 2013.12.006 (2014).

24. Rovere, A. et al. Submerged reef terraces in the Maldivian Archipelago (Indian Ocean). Geomorphology 317, 218-232. https://doi. org/10.1016/j.geomorph.2018.05.026 (2018).

25. Rees, S., Opdyke, B., Wilson, P. \& Henstock, T. Significance of Halimeda bioherms to the global carbonate budget based on a geological sediment budget for the Northern Great Barrier Reef Australia. Coral Reefs 26, 177-188. https://doi.org/10.1007/s00338006-0166-x (2007).

26. McNeil, M. A., Webster, J. M., Beaman, R. J. \& Graham, T. L. New constraints on the spatial distribution and morphology of the Halimeda bioherms of the Great Barrier Reef, Australia. Coral Reefs 35, 1343-1355. https://doi.org/10.1007/s00338-016-1492-2 (2016).

27. McNeil, M., Nothdurft, L., Dyriw, N. J., Webster, J. M. \& Beaman, R. J. Morphotype differentiation in the Great Barrier Reef Halimeda bioherm carbonate factory: Internal architecture and surface geomorphometrics. Depos. Rec. https://doi.org/10.1002/ dep2.122 (2020).

28. Smith, S. V. Coral-reef area and the contributions of reefs to processes and resources of the world's oceans. Nature 273, 225. https:// doi.org/10.1038/273225a0 (1978).

29. GBRMPA. Great Barrier Reef Features (Reef boundaries, QLD Mainland, Islands, Cays and Rocks). (Great Barrier Reef Marine Park Authority, 2013).

30. Webster, J. M., Yokoyama, Y., Cotterill, C. \& Expedition 325 Scientists. in Proceedings of the Integrated Ocean Drilling Program (Integrated Ocean Drilling Program Management International, Inc., for the Integrated Ocean Drilling Program, 2011).

31. Yokoyama, Y. et al. Rapid glaciation and a two-step sea level plunge into the Last Glacial Maximum. Nature 559, 603-607. https:// doi.org/10.1038/s41586-018-0335-4 (2018).

32. Tilbrook, B. \& Matear, R. RV Southern Surveyor-Voyage Summary SS09/2008: Carbon Geochemistry of the Great Barrier Reef (Marine National Facility, 2008).

33. Webster, J. M., Davies, P. J., Beaman, R. J, William, S. \& Byrne, M. RV Southern Surveyor-Voyage Summary SS07/2007. 18 (Marine National Facility 2008)

34. Abbey, E., Webster, J. M. \& Beaman, R. J. Geomorphology of submerged reefs on the shelf edge of the Great Barrier Reef: The influence of oscillating Pleistocene sea-levels. Mar. Geol. 288, 61-78. https://doi.org/10.1016/j.margeo.2011.08.006 (2011).

35. Renema, W., Beaman, R. J. \& Webster, J. M. Mixing of relict and modern tests of larger benthic foraminifera on the Great Barrier Reef shelf margin. Mar. Micropaleontol. 101, 68-75. https://doi.org/10.1016/j.marmicro.2013.03.002 (2013).

36. Abbey, E. et al. Deglacial mesophotic reef demise on the Great Barrier Reef. Palaeogeogr. Palaeoclimatol. Palaeoecol. 392, 473-494. https://doi.org/10.1016/j.palaeo.2013.09.032 (2013).

37. Alexander, I. et al. New constraints on the origin of the Australian Great Barrier Reef from an international project of deep coring. Geology 29, 483-486. https://doi.org/10.1130/0091-7613(2001)029\%3c0483:NCOTOO\%3e2.0.CO;2 (2001).

38. Humblet, M. \& Webster, J. M. Coral community changes in the Great Barrier Reef in response to major environmental changes over glacial-interglacial timescales. Palaeogeogr. Palaeoclimatol. Palaeoecol. 472, 216-235. https://doi.org/10.1016/j.palaeo.2017. $02.003(2017)$.

39. Lambeck, K., Rouby, H., Purcell, A., Sun, Y. \& Sambridge, M. Sea level and global ice volumes from the Last Glacial Maximum to the Holocene. Proc. Natl. Acad. Sci. U.S.A. https://doi.org/10.1073/pnas.1411762111 (2014). 
40. Hinestrosa, G., Webster, J. M. \& Beaman, R. J. Postglacial sediment deposition along a mixed carbonate-siliciclastic margin: New constraints from the drowned shelf-edge reefs of the Great Barrier Reef, Australia. Palaeogeogr. Palaeoclimatol. Palaeoecol. 446, 168-185. https://doi.org/10.1016/j.palaeo.2016.01.023 (2016).

41. Beaman, R. J., Webster, J. M. \& Wust, R. A. J. New evidence for drowned shelf edge reefs in the Great Barrier Reef, Australia. Mar. Geol. 247, 17-34. https://doi.org/10.1016/j.margeo.2007.08.001 (2008).

42. Doblin, M. A. et al. RV Southern Surveyor-Voyage Summary T03/SS2013 (Marine National Facility, 2013).

43. Bostock, H. C., Opdyke, B. N., Gagan, M. K. \& Fifield, L. K. Late Quaternary siliciclastic/carbonate sedimentation model for the Capricorn Channel, southern Great Barrier Reef province, Australia. Mar. Geol. 257, 107-123. https://doi.org/10.1016/j.margeo. 2008.11.003 (2009).

44. Dunbar, G. B., Dickens, G. R. \& Carter, R. M. Sediment flux across the Great Barrier Reef Shelf to the Queensland Trough over the last 300 ky. Sed. Geol. 133, 49. https://doi.org/10.1016/S0037-0738(00)00027-0 (2000).

45. Harper, B. B. et al. Mixed carbonate-siliciclastic sedimentation along the Great Barrier Reef upper slope: A challenge to the reciprocal sedimentation model. J. Sediment. Res. 85, 1019-1036. https://doi.org/10.2110/jsr.2015.58.1 (2015).

46. Beaman, R. J. et al. in Seafloor Geomorphology as Benthic Habitat: GeoHab Atlas of Seafloor Geomorphic Features and Benthic Habitats (ed P.T. Harris, Baker, E.K.) 425-434 (Elsevier, 2011).

47. Hinestrosa, G., Webster, J. M., Beaman, R. J. \& Anderson, L. M. Seismic stratigraphy and development of the shelf-edge reefs of the Great Barrier Reef, Australia. Mar. Geol. 353, 1-20. https://doi.org/10.1016/j.margeo.2014.03.016 (2014).

48. Davies, P. J. \& Hopley, D. Growth fabrics and growth rates of Holocene reefs in the Great Barrier Reef. BMR J. Aust. Geol. Geophys. 8, 237-251 (1983).

49. Hinestrosa, G., Webster, J. M. \& Beaman, R. J. Spatio-temporal patterns in the postglacial flooding of the Great Barrier Reef shelf, Australia. Cont. Shelf Res. 173, 13-26. https://doi.org/10.1016/j.csr.2018.12.001 (2019).

50. Harris, P. T. et al. Submerged banks in the Great Barrier Reef, Australia, greatly increase available coral reef habitat. ICES J. Mar. Sci. 70, 284-293. https://doi.org/10.1093/icesjms/fss165 (2012).

51. Heap, A. D., Harris, P. T. \& Fountain, L. Neritic carbonate for six submerged coral reefs from northern Australia: Implications for Holocene global carbon dioxide. Palaeogeogr. Palaeoclimatol. Palaeoecol. 283, 77-90. https://doi.org/10.1016/j.palaeo.2009.08.003 (2009).

52. Seard, C., Borgomano, J., Granjeon, D. \& Camoin, G. Impact of environmental parameters on coral reef development and drowning: Forward modelling of the last deglacial reefs from Tahiti (French Polynesia; IODP Expedition \#310). Sedimentology https:// doi.org/10.1111/sed.12030 (2013).

53. Camoin, G. et al. in EGU General Assembly 2009 Conference Abstracts. 1994.

54. Montaggioni, L. F. \& Braithwaite, C. J. R. in Developments in Marine Geology Vol. 5550 (Elsevier, 2009).

55. Kinsey, D. W. \& Hopley, D. The significance of corals reefs as global carbon sinks-Response to Greenhouse. Palaeogeogr. Palaeoclimatol. Palaeoecol. 89, 363-377. https://doi.org/10.1016/0031-0182(91)90172-N (1991).

56. Spalding, M. D., Ravilious, C. \& Green, E. World Atlas of Coral Reefs (University of California Press, Berkeley, 2001).

57. Beaman, R. J. 3DGBR: A high-resolution depth model for the Great Barrier Reef and Coral Sea. 12 (2010).

58. Kleypas, J. A. Modeled estimates of global reef habitat and carbonate production since the Last Glacial Maximum. Paleoceanography 12, 533-545. https://doi.org/10.1029/97pa01134 (1997).

59. Drew, E. A. \& Abel, K. M. in Proceedings of The Fifth International Coral Reef Congress. 15-20.

60. Orme, G. R. \& Salama, M. S. Form and seismic stratigraphy of Halimeda banks in part of the northern Great Barrier Reef Province. Coral Reefs 6, 131-137. https://doi.org/10.1007/BF00302009 (1988).

61. Vecsei, A. A new estimate of global reefal carbonate production including the fore-reefs. Global Planet. Change 43, 1-18. https:// doi.org/10.1016/j.gloplacha.2003.12.002 (2004).

62. Sloss, P. W. (Marine Geology and Geophysics Division, N.G.D.C. (Ed.), Boulder, Colorado., 1986).

63. Rees, S., Opdyke, B., Wilson, P., Keith Fifield, L. \& Levchenko, V. Holocene evolution of the granite based Lizard Island and MacGillivray Reef systems, Northern Great Barrier Reef. Coral Reefs 25, 555-565. https://doi.org/10.1007/s00338-006-0138-1 (2006).

64. De Vooys, C. in Scientific Committee on Problems of the Environment (SCOPE) Series (1979).

65. Copper, P. Ancient reef ecosystem expansion and collapse. Coral Reefs 13, 3-11. https://doi.org/10.1007/BF00426428 (1994).

66. Vecsei, A. \& Berger, W. H. Increase of atmospheric $\mathrm{CO}_{2}$ during deglaciation: Constraints on the coral reef hypothesis from patterns of deposition. Global Biogeochem. Cycles https://doi.org/10.1029/2003gb002147 (2004).

67. Bauska, T. K., Marcott, S. A. \& Brook, E. J. Abrupt changes in the global carbon cycle during the last glacial period. Nat. Geosci. 14, 91-96. https://doi.org/10.1038/s41561-020-00680-2 (2021).

68. Hopley, D., Smithers, S. G. \& Parnell, K. E. The Geomorphology of the Great Barrier Reef (Cambridge, 2007).

69. Honisch, B. et al. The geological record of ocean acidification. Science 335, 1058-1063. https://doi.org/10.1126/science.1208277 (2012).

70. Ridgwell, A., Zondervan, I., Hargreaves, J. C., Bijma, J. \& Lenton, T. M. Assessing the potential long-term increase of oceanic fossil fuel $\mathrm{CO}_{2}$ uptake due to $\mathrm{CO}_{2}$-calcification feedback. Biogeosciences 4, 481-492. https://doi.org/10.5194/bg-4-481-2007 (2007).

71. Andersson, A. J. \& Mackenzie, F. T. Shallow-water oceans: a source or sink of atmospheric CO2?. Front. Ecol. Environ. 2, 348-353. https://doi.org/10.1890/1540-9295(2004)002[0348:Soasos]2.0.Co;2 (2004).

72. Wollast, R., Garrels, R. M. \& Mackenzie, F. T. Calcite-seawater reactions in ocean surface waters. Am. J. Sci. 280, 831-848. https:// doi.org/10.2475/ajs.280.9.831 (1980).

73. Newell, N. D. An outline history of tropical organic reefs. Am. Mus. Novit. 2465, 1-37 (1971).

74. Milliman, J., Mueller, G. \& Foerstner, U. Marine Carbonates. Recent Sedimentary Carbonates, Part 1 (Springer-Verlag, 1974).

75. Hillis, L. Coralgal reefs from a calcareous green algal perspective and a first carbonate budget. In: Proceedings of the 8th International Coral Reef Symposium (eds. Lessios, H.A., \& Macintyre, I.G.,)Vol. 1. 761-766. (Smithsonian Tropical Research Institute, Panama, 1997).

\section{Acknowledgements}

Thanks to Thomas Felis for the insights on the carbon isotopic cycle and its relation to Quaternary coral reef growth. Financial support was provided by the Australian Research Council (grant no. DP1094001) and ANZIC (Australian and New Zealand International Ocean Discovery Program). Research supported by a grant of sea time on RV Southern Surveyor from the CSIRO Marine National Facility.

\section{Author contributions}

G.H. collated the data and literature, did the volumetric and mass calculations, wrote the manuscript, prepared the figures and tables following discussions with the other authors.J.W. collected field data, provided the knowhow on the reef core datasets and on interpretations of the geological history of the Great Barrier Reef and its relation to the evolution of the carbonate volumes in the shelf and shelf edge.R.B. collected field data, provided 
the bathymetric-satellite datasets and interpretations on the geomorphology of the Great Barrier Reef and its relation to the evolution of the carbonate volumes in the shelf and shelf edge.

\section{Competing interests}

The authors declare no competing interests.

\section{Additional information}

Supplementary Information The online version contains supplementary material available at https://doi.org/ 10.1038/s41598-021-04586-w.

Correspondence and requests for materials should be addressed to G.H.

Reprints and permissions information is available at www.nature.com/reprints.

Publisher's note Springer Nature remains neutral with regard to jurisdictional claims in published maps and institutional affiliations.

(c) (i) Open Access This article is licensed under a Creative Commons Attribution 4.0 International License, which permits use, sharing, adaptation, distribution and reproduction in any medium or format, as long as you give appropriate credit to the original author(s) and the source, provide a link to the Creative Commons licence, and indicate if changes were made. The images or other third party material in this article are included in the article's Creative Commons licence, unless indicated otherwise in a credit line to the material. If material is not included in the article's Creative Commons licence and your intended use is not permitted by statutory regulation or exceeds the permitted use, you will need to obtain permission directly from the copyright holder. To view a copy of this licence, visit http://creativecommons.org/licenses/by/4.0/.

(C) The Author(s) 2022, corrected publication 2022 